\title{
Crustal noble gases in deep brines as natural tracers of vertical transport processes in the Michigan Basin
}

\author{
Lin Ma, Maria Clara Castro, and Chris M. Hall \\ Department of Geological Sciences, University of Michigan, 2534 C.C. Little Building, Ann Arbor, Michigan 48109, \\ USA (linma@umich.edu; mccastro@umich.edu; cmhall@umich.edu)
}

[1] Noble gas concentrations and isotopic ratios are presented for 38 deep $(\sim 0.5-3.6 \mathrm{~km})$ brine samples in the Michigan Basin. These brine samples clearly show the presence of an important crustal component of ${ }^{4} \mathrm{He},{ }^{21} \mathrm{Ne},{ }^{40} \mathrm{Ar}$, and ${ }^{136} \mathrm{Xe}$. Both ${ }^{40} \mathrm{Ar}_{\text {crust }}$ and ${ }^{136} \mathrm{Xe}_{\text {crust }}$ display the presence of a strong vertical gradient along the sedimentary strata of the basin. We show that the in situ production for these two gases within the sedimentary strata is insufficient to account for the observed crustal component in the Michigan brines. These point to the presence of a deep, external source for crustal noble gases, likely the Precambrian crystalline basement beneath the Michigan Basin. Furthermore, observed elemental ratios of crustal noble gases $\left({ }^{4} \mathrm{He} /{ }^{40} \mathrm{Ar},{ }^{21} \mathrm{Ne} /{ }^{40} \mathrm{Ar},{ }^{4} \mathrm{He} /{ }^{136} \mathrm{Xe}\right.$, and $\left.{ }^{21} \mathrm{Ne} /{ }^{136} \mathrm{Xe}\right)$ in these brines vary over several orders of magnitude with respect to the expected production ratios from the crystalline basement rocks and display a systematic pattern within the basin. Specifically, samples above the Salina Group (shallow formations) are relatively enriched in ${ }^{4} \mathrm{He}_{\text {crust }}$ and ${ }^{21} \mathrm{Ne}_{\text {crust }}$ with respect to ${ }^{40} \mathrm{Ar}_{\text {crust }}$ and ${ }^{136} \mathrm{Xe}_{\text {crust }}$, as opposed to those below the massive Salina evaporite layer (deeper formations) which exhibit complementary patterns. We show that such a general trend is best explained by a Rayleigh-type elemental fractionation model involving upward transport of crustal noble gases and associated elemental fractionation processes, controlled by both diffusion- and solubility-related mechanisms. As previously indicated by the mantle and atmospheric noble gas signatures in these same Michigan brine samples, release of deep crustal noble gases into the basin is yet another independent indicator pointing to the occurrence of a past thermal event in the basin. We suggest that recent reactivation of the ancient midcontinent rift system underneath the Michigan Basin is likely responsible for the upward transport of heat and loss of the atmospheric noble gas component, as well as release of crustal (still ongoing) and mantle noble gases into the basin via deepseated faults and fracture zones. Such a model also supports an internal heat source hypothesis as being largely responsible for the existence of past high temperatures in the basin without involvement of largescale brine migration from peripheral forming orogenic fold belts.

Components: 12,907 words, 7 figures, 5 tables.

Keywords: crustal noble gases; vertical transport; brines; Michigan Basin; thermal event.

Index Terms: 1040 Geochemistry: Radiogenic isotope geochemistry; 1832 Hydrology: Groundwater transport.

Received 4 March 2009; Revised 8 April 2009; Accepted 15 April 2009; Published 3 June 2009.

Ma, L., M. C. Castro, and C. M. Hall (2009), Crustal noble gases in deep brines as natural tracers of vertical transport processes in the Michigan Basin, Geochem. Geophys. Geosyst., 10, Q06001, doi:10.1029/2009GC002475. 


\section{Introduction}

[2] Because of their conservative nature and because of their specific characteristics depending on their origin (atmosphere, crust, mantle), noble gases ( $\mathrm{He}, \mathrm{Ne}, \mathrm{Ar}, \mathrm{Kr}, \mathrm{Xe}$ ) are a powerful tool to investigate the origin and evolution of crustal fluids in sedimentary basins [e.g., Oxburgh et al., 1986; Hiyagon and Kennedy, 1992; O'Nions and Ballentine, 1993; Pinti and Marty, 1995; Castro et al., 1998a, 1998b; Patriarche et al., 2004; Kulongoski et al., 2005]. In particular, concentrations of certain noble gases in deep groundwaters frequently exceed those expected for water in solubility equilibrium with the atmosphere (Air Saturated Water (ASW)). Although mantle noble gases are commonly present in subsurface fluids [e.g., Oxburgh et al., 1986], these excesses result mainly from crustal production of: a) ${ }^{4} \mathrm{He}$ and ${ }^{40} \mathrm{Ar}$ from radioactive decay of $\mathrm{U} / \mathrm{Th}$ and ${ }^{40} \mathrm{~K}$, respectively; $\left.\mathrm{b}\right){ }^{21} \mathrm{Ne}$ from secondary $\alpha$ or $\mathrm{n}$ reactions on target elements such as $\mathrm{O}$ and $\mathrm{Mg}$, and: c) ${ }^{131}, 132,134,{ }^{136} \mathrm{Xe}$ isotopes from spontaneous fission of $U$ [e.g., Wetherill, 1953, 1954; Ballentine and Burnard, 2002]. Crustal noble gases may be produced inside the aquifer (in situ production) or in deeper layers (external production). Noble gases will be subsequently transported to shallower levels by advection, dispersion and/or diffusion or by a combination of these processes [e.g., Castro et al., 1998a, 1998b; Castro and Goblet, 2003]. Although chemically inert and stable, noble gases display contrasting physical properties due to their large differences in atomic numbers. In particular, their solubilities in water vary by over an order of magnitude [Ozima and Podosek, 2002], while molecular diffusivities, from $\mathrm{He}$ to $\mathrm{Xe}$, vary by a factor of 7 at a temperature of $0^{\circ} \mathrm{C}$ [Jähne et al., 1987]. Noble gases are thus very sensitive to physical processes during subsurface transport and as a result, their concentrations and elemental ratios have been widely used as geochemical tracers of subsurface fluid movement in major sedimentary systems around the world (e.g., the Great Artesian Basin in Australia [Torgersen and Clarke, 1985; Torgersen et al., 1989], the Pannonian Basin in Hungary [Ballentine et al., 1991], the Paris Basin in France [Pinti and Marty, 1995; Castro et al., 1998a, 1998b], the Witwatersrand Basin in South Africa [Lippmann et al., 2003] and the Gulf Coast Basin in the USA [Castro et al., 2005]).

[3] In addition, when combined with heat flow, the study of ${ }^{4} \mathrm{He}$ in crustal fluids allows for the reconstruction of the thermal and tectonic history of continental regions [Castro et al., 2005]. More specifically, Castro et al. [2005] have shown that the occurrence of a ${ }^{4} \mathrm{He} /$ heat flux ratio greater than the radiogenic production ratio can only result from a past thermal event of mantle origin in which most of the heat has already escaped while He is slowly making its way toward the surface. Such a high ${ }^{4} \mathrm{He} /$ heat flux ratio was recently identified in shallow $(<100 \mathrm{~m})$ groundwaters of the Marshall aquifer in the Michigan Basin [Ma et al., 2005; M. C. Castro et al., $4 \mathrm{He} /$ heat flux ratios as new indicators of past thermal and tectonic events-New constrains on the tectonothermal history of the Michigan Basin, paper presented at 4th Mini Conference on Noble Gases in the Hydrosphere and in Natural Gas Reservoirs, GFZ Potsdam, Potsdam, Germany, 28 February to 2 March 2007]. To confirm the occurrence of such a thermal event and to clarify its origin, 38 deep $(0.5-3.6 \mathrm{~km})$ brine samples were collected and analyzed for noble gas concentrations and isotopic ratios in the Michigan Basin [Castro et al., 2009; Ma et al., 2009; this study]. While both $\mathrm{He}$ and $\mathrm{Ne}$ isotopic ratios clearly indicate the presence of a mantle component, $\mathrm{Ne}$ isotopic compositions point unequivocally to the presence of a primordial, solar-like signature in this continental region, thus, confirming the mantle origin of this past thermal event [Castro et al., 2009]. In addition, depletion of atmospheric noble gases in these brines is also observed and is best explained by a model involving subsurface boiling and steam separation. The atmospheric component of noble gases provides thus an additional independent indicator of the occurrence of a past thermal event in this system [Ma et al., 2009].

[4] Here, we present a companion study that focuses on the crustally produced noble gases $\left({ }^{4} \mathrm{He}_{\text {crust }}\right.$, ${ }^{21} \mathrm{Ne}_{\text {crust }},{ }^{40} \mathrm{Ar}_{\text {crust }}$ and $\left.{ }^{136} \mathrm{Xe}_{\text {crust }}\right)$ present in the Michigan Basin brines. Specifically, we show that the crustal noble gas component in these brines originated mainly from the Precambrian basement underneath the Michigan Basin and that their distribution patterns can be best explained by a model involving vertical upward transport and associated elemental fractionation during both diffusion- and solubility-controlled processes. Release of these deep crustal noble gases into the basin also points to the occurrence of a past thermal event in the basin, as previously suggested by heat and mantle noble gases release [Castro et al., 2009; Ma et al., 2009]. Such a release is most likely related to the recent reactivation of the midcontinent rift (MCR) system underneath the Michigan Basin and highlights the 

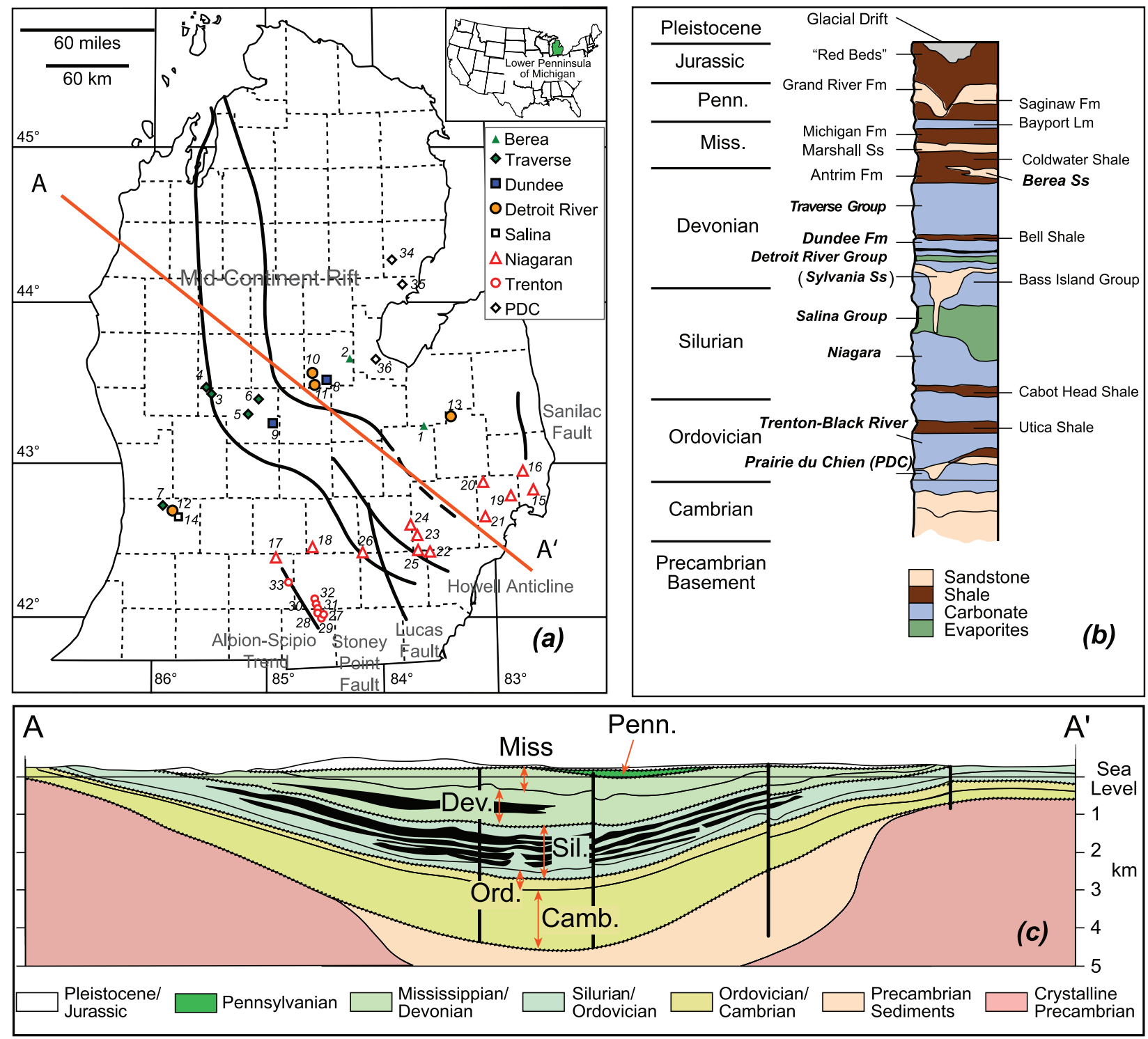

Figure 1. (a) Central portion of the Michigan Basin (lower peninsula of Michigan). Major tectonic structures (e.g., midcontinental rift) and sample locations are indicated [after Dorr and Eschman, 1970; Fisher et al., 1988; Catacosinos et al., 1991]. (b) Stratigraphic succession of the Michigan Basin. Major lithologies present in the basin are identified; units for which formation brines were sampled in this study are highlighted in bold. (c) General schematic geological representation along cross section $\mathrm{A}-\mathrm{A}^{\prime}$.

impact of tectonic activity in deep crustal degassing processes. Our study highlights the use of crustally produced noble gases to trace subsurface fluid movement and to study the thermal history of currently stable regions.

\section{Geological and Hydrogeologic Background}

[5] The Michigan Basin is a concentric intracratonic depression floored by crystalline Precambrian basement, and consists of a succession of sedimen- tary rocks with ages from Precambrian to Jurassic that reaches depths over $5 \mathrm{~km}$ (Figure 1) [Dorr and Eschman, 1970; Catacosinos et al., 1991]. The entire sedimentary strata are composed mainly of evaporites, carbonates, shale, and sandstone underneath a thick layer of Pleistocene glacial deposits (Figure 1b). Depending on their nature, these sedimentary rocks constitute either aquitards (e.g., shale, evaporites) or aquifers (mostly sandstones and reefal and dolomitized limestones), giving origin to a multilayered aquifer system [Vugrinovich, 1986]. 
[6] Major tectonic structures such as the AlbionScipio Fault, the Lucas Fault, and the Howell Anticline are present in southern Michigan and penetrate the crystalline basement, which is mainly composed of Precambrian $(\sim 1.1$ to $>2.5 \mathrm{Ga})$ igneous-metamorphic rocks (Figure 1a). The basement is believed to have a well-developed pattern of jointing and faulting, similar to the highly fractured neighboring Canadian Shield outcrop [Sanford et al., 1985; Fisher et al., 1988]. A rift zone that formed during an episode of crustal extension at $\sim 1.1 \mathrm{Ga}$ transects the entire crystalline basement of the Michigan Basin (Figure 1a), and is believed to be part of the MCR system [Hinze et al., 1975; Van Schmus, 1992]. Repeated movements along major faults in southern Michigan prevailed throughout the early part of the Paleozoic and major uplift of most of the basin fault blocks occurred at the end of the Mississippian Period ( $320 \mathrm{Ma})$ [Fisher et al., 1988].

[7] Despite the current low geothermal gradient in the basin $\left(\sim 19^{\circ} \mathrm{C} / \mathrm{km}\right)$ [Vugrinovich, 1989], oil and natural gas reservoirs in southern Michigan are abundant and ubiquitously distributed within the sedimentary sequence, from the deep Ordovician to the shallow Mississippian (Figure 1b) [Dorr and Eschman, 1970; Catacosinos et al., 1991], indicating the occurrence of higher temperatures in the past. A wealth of thermal studies in the basin based on a diversity of proxies (e.g., organic maturity data, stable isotopes, fluid inclusions, authigenic clay minerals, apatite fission track ages) point to the occurrence of high temperatures (up to $260^{\circ} \mathrm{C}$ ) in the past [Cercone and Lohmann, 1987; Cercone and Pollack, 1991; Crowley, 1991; Coniglio et al., 1994; Girard and Barnes, 1995; Luczaj et al., 2006]. The origin and thermal history of such reservoirs, however, remain uncertain. Because these high temperatures cannot be easily explained by long-term deep burial [e.g., Cercone, 1984; Vugrinovich, 1988; Luczaj et al., 2006], models involving transport of heat and fluids from deeper parts of the basin along major faults and fracture zones connected to the Precambrian basement structures were proposed [Sanford et al., 1985; Budai and Wilson, 1991; Coniglio et al., 1994; Girard and Barnes, 1995; Luczaj et al., 2006].

[8] In addition to oil and natural gas, formation waters (brines) with very high salinities (e.g., total dissolved solids $>450 \mathrm{~g} \mathrm{~L}^{-1}$ ) distributed throughout the basin have also been documented [Long et al., 1988; Wilson and Long, 1993a, 1993b; Martini, 1997; McIntosh et al., 2004]. Studies of major elements and stable isotopes suggest that these deep basinal brines originated from ancient seawater and have a complex evolution history involving intensive water-rock interactions, dissolution of evaporites, as well as mixing with meteoric and seawater [Long et al., 1988; Wilson and Long, 1993a, 1993b; Davisson and Criss, 1996; Martini, 1997; McIntosh et al., 2004]. Upward transport of fluids was also suggested to account for the presence of extremely high salinity waters [Long et al., 1988] as well as unusually high ${ }^{4} \mathrm{He}$ excesses and fluxes at shallow depths [Ma et al., 2005].

\section{Sampling Techniques and Experimental Methods}

[9] A total of 38 brine samples were collected from eight formations in the Michigan Basin for noble gas analysis (Figures 1a and 1b). Brines were sampled from actively pumping wells in copper tubes (i.e., standard refrigeration grade $3 / 8^{\prime \prime} \mathrm{Cu}$ tubing) that were sealed by stainless steel pinch-off clamps [Weiss, 1968] at wellhead pressures after water was allowed to flow through for $\sim 10 \mathrm{~min}$ to avoid atmospheric contamination and to ensure that water temperature had reached equilibrium. Elemental and isotopic noble gas measurements were performed at the University of Michigan as described briefly below and in detail elsewhere $[\mathrm{Ma}$ et al., 2004; Saar et al., 2005, Castro et al., 2009].

[10] Brine samples $(\sim 14 \mathrm{ml})$ were attached to a vacuum extraction system and noble gases were quantitatively extracted for inletting into a MAP215 mass spectrometer. Noble gases were transported using water vapor as a carrier gas through two constrictions in the vacuum system, purified by two Ti sponge getters, and sequentially allowed to enter a MAP-215 mass spectrometer using a cryoseparator. The cryoseparator temperatures were set at $30,60,180,215$, and $270 \mathrm{~K}$ for analysis of $\mathrm{He}, \mathrm{Ne}, \mathrm{Ar}, \mathrm{Kr}$, and $\mathrm{Xe}$, respectively. ${ }^{4} \mathrm{He},{ }^{20} \mathrm{Ne}$, and ${ }^{40} \mathrm{Ar}$ isotopes were measured using a Faraday detector and ${ }^{3} \mathrm{He},{ }^{21,}{ }^{22} \mathrm{Ne},{ }^{36,38} \mathrm{Ar}$, as well as ${ }^{80,82 \text {, }}$ ${ }^{83,84,86} \mathrm{Kr}$ and ${ }^{136,134,132,131,130,129,128} \mathrm{Xe}$ isotopes were measured using an electron multiplier in ion counting mode. During neon isotope analysis, a liquid $\mathrm{N}_{2}$ cold trap was applied to minimize peak interferences and appropriate mass peaks were monitored to correct for interferences of ${ }^{40} \mathrm{Ar}^{2+}$ and $\mathrm{H}_{2}^{18} \mathrm{O}^{+}$on ${ }^{20} \mathrm{Ne}$, and $\mathrm{CO}_{2}^{2+}$ on ${ }^{22} \mathrm{Ne}$. The interference corrections for ${ }^{20} \mathrm{Ne}$ and ${ }^{22} \mathrm{Ne}$ were typically $\sim 1.1 \%$ and $0.17 \%$, respectively. Before each sample analysis, a calibrated amount of air standard and a procedural blank were performed 
following the same procedure of the sample measurement. The blank correction was applied to all measured peaks. ${ }^{4} \mathrm{He},{ }^{22} \mathrm{Ne},{ }^{36} \mathrm{Ar},{ }^{84} \mathrm{Kr}$, and ${ }^{130} \mathrm{Xe}$ elemental abundances and their respective isotopic ratios for each sample were normalized to the air standard after blank correction. Blank correction for ${ }^{4} \mathrm{He},{ }^{36} \mathrm{Ar},{ }^{84} \mathrm{Kr}$, and ${ }^{130} \mathrm{Xe}$ is negligible. The average measured sample/blank signal size ratio for ${ }^{22} \mathrm{Ne}$ is about $15 .{ }^{4} \mathrm{He},{ }^{22} \mathrm{Ne},{ }^{36} \mathrm{Ar},{ }^{84} \mathrm{Kr}$, and ${ }^{130} \mathrm{Xe}$ abundances have typical uncertainties of 1.5, 1.3, 1.3, 1.5 and $2.2 \%$, respectively. All uncertainties are at $\pm 1 \sigma$ level of confidence. The whole procedure was tested and calibrated with synthetic laboratory fresh water samples produced at a known temperature.

\section{Results}

[11] Noble gas isotopic ratios (Ar, $\mathrm{Kr}$, and $\mathrm{Xe}$ ), sample numbers, formation, lithology as well as sample depths are reported in Table 1a (see also Table 1b). Atmospheric isotopic ratios are also listed for reference. He and $\mathrm{Ne}$ isotopic ratios, as well as atmospheric noble gas components of these brine samples have been reported and discussed elsewhere [Castro et al., 2009; Ma et al., 2009].

\subsection{Isotopic Ratios of Noble Gases in Michigan Basin Brines}

[12] ${ }^{3} \mathrm{He} /{ }^{4} \mathrm{He}(\mathrm{R})$ ratios in Michigan Basin brines vary from $0.053 \pm 0.009$ times the atmospheric ratio $\mathrm{Ra}$, a typical crustal production value ( 0.01-0.05) [e.g., Oxburgh et al., 1986], to $1.29 \pm 0.27$ (Figure 2a [Castro et al., 2009]). Because atmospheric He contribution is negligible in these brines [Castro et al., 2009], the measured $\mathrm{R} / \mathrm{Ra}$ ratios represent only a mixture of crustal and mantle He components. Typical crustal $\mathrm{R} / \mathrm{Ra}$ production values are 0.01-0.05 [e.g., Oxburgh et al., 1986] because of the dominant production of ${ }^{4} \mathrm{He}$ from $\mathrm{U}$ and $\mathrm{Th}$ decay; mantle $\mathrm{R} / \mathrm{Ra}$ ratios are much greater because of the presence of primordial ${ }^{3} \mathrm{He}$ in the mantle, e.g., $\sim 8$ in the mantle MORB source region and $\sim 35$ in the OIB source regions [e.g., Graham, 2002]. Measured R/Ra ratios in our brine samples are greater than typical crustal values (Figure 2a), strongly pointing to the presence of a mantle $\mathrm{He}$ component. Using a mantle $\mathrm{R} / \mathrm{Ra}$ value of 8 and a crustal production value of 0.05 , crustal ${ }^{4} \mathrm{He}$ contributions in these samples vary between $84.4 \%$ and $100 \%$ of total measured ${ }^{4} \mathrm{He}$, with a mantle ${ }^{4} \mathrm{He}$ contribution of up to $\sim 15.6 \%$.

[13] Measured ${ }^{20} \mathrm{Ne} /{ }^{22} \mathrm{Ne}$ ratios are greater than the air value (9.8) and suggest also the presence of mantle $\mathrm{Ne}$ in these samples [Castro et al., 2009]. ${ }^{21} \mathrm{Ne} /{ }^{22} \mathrm{Ne}$ ratios range from $0.0290 \pm 0.0002$ to $0.0432 \pm 0.0004$ (Figure 2b) reflecting the addition of crustally produced ${ }^{21} \mathrm{Ne}$ through the nuclear reactions of ${ }^{18} \mathrm{O}(\alpha, \mathrm{n}){ }^{21} \mathrm{Ne}$ and ${ }^{24} \mathrm{Mg}(\mathrm{n}, \alpha)^{21} \mathrm{Ne}$ [Wetherill, 1954]. Simultaneous analysis of both ${ }^{20} \mathrm{Ne} /{ }^{22} \mathrm{Ne}$ and ${ }^{21} \mathrm{Ne} /{ }^{22} \mathrm{Ne}$ ratios allows separation of the atmospheric, crustal, and mantle Ne components as the three sources all have distinct endmember values [Castro et al., 2009]. Analysis of $\mathrm{Ne}$ isotopic ratios in these brines indicates an atmospheric ${ }^{21} \mathrm{Ne}$ contribution varying from $57.7 \%$ to $96.9 \%$ of total measured ${ }^{21} \mathrm{Ne}$, a crustal ${ }^{21} \mathrm{Ne}$ contribution varying between $0.5 \%$ and $35.1 \%$, and a mantle ${ }^{21} \mathrm{Ne}$ contribution ranging from $2.6 \%$ to $26.9 \%$ [Castro et al., 2009].

[14] ${ }^{40} \mathrm{Ar} /{ }^{36} \mathrm{Ar}$ ratios of these brine samples are all above the atmospheric value (295.5) and reflect the addition of radiogenic ${ }^{40} \mathrm{Ar}$. These vary between $299.8 \pm 1.9$ and $2863.1 \pm 55.5$, the higher values being found in the deeper formations (Niagaran, Trenton, and PDC; Table 1a and Figure 2c). This ratio increases rapidly with depth and displays a marked isotopic gradient along the sedimentary sequence (Figure 2c), pointing to a deeper source of radiogenic ${ }^{40} \mathrm{Ar}$. Similar to ${ }^{4} \mathrm{He}$, excesses of ${ }^{40} \mathrm{Ar}$ are commonly observed in old crustal fluids due to natural decay of ${ }^{40} \mathrm{~K}$. Unfortunately, the exact crustal and mantle contributions of ${ }^{40} \mathrm{Ar}$ cannot be effectively separated because of current uncertainties of both ${ }^{40} \mathrm{Ar} /{ }^{36} \mathrm{Ar}$ and ${ }^{38} \mathrm{Ar} /{ }^{36} \mathrm{Ar}$ endmember values. As inferred from the $\mathrm{He}$ isotopic analysis in these brines, excess ${ }^{40} \mathrm{Ar}$ results mostly from crustally produced ${ }^{40} \mathrm{Ar}$, although the presence of a small mantle ${ }^{40} \mathrm{Ar}$ contribution $(\leq 16 \%)$ cannot be completely ruled out. The likely presence of a dominant crustal ${ }^{40} \mathrm{Ar}$ component in these samples is further discussed below.

[15] $\mathrm{Kr}$ isotopic ratios (e.g., ${ }^{86} \mathrm{Kr} /{ }^{84} \mathrm{Kr}$; Table 1a) are all indistinguishable from the atmospheric value (Table 1a). Kr will thus not be the object of further discussion in the present document.

[16] ${ }^{136} \mathrm{Xe} /{ }^{130} \mathrm{Xe}$ ratios of Michigan brines show values above the atmospheric ratio (2.176), up to $2.365 \pm 0.012$ in the deepest formation (PDC), clearly showing the presence of excess ${ }^{136} \mathrm{Xe}$ (Table 1a and Figure 2d). Similar to ${ }^{40} \mathrm{Ar} /{ }^{36} \mathrm{Ar}$ ratios, ${ }^{136} \mathrm{Xe} /{ }^{130} \mathrm{Xe}$ ratios also display a strong vertical gradient along the sedimentary strata, suggesting a deeper source for this excess ${ }^{136} \mathrm{Xe}$ (Figure 2d). Similar gradients are also observed with ${ }^{134} \mathrm{Xe} /{ }^{130} \mathrm{Xe}$ and ${ }^{132} \mathrm{Xe} /{ }^{130} \mathrm{Xe}$ ratios (Table 1a). These elevated $X e$ isotopic ratios suggest the 


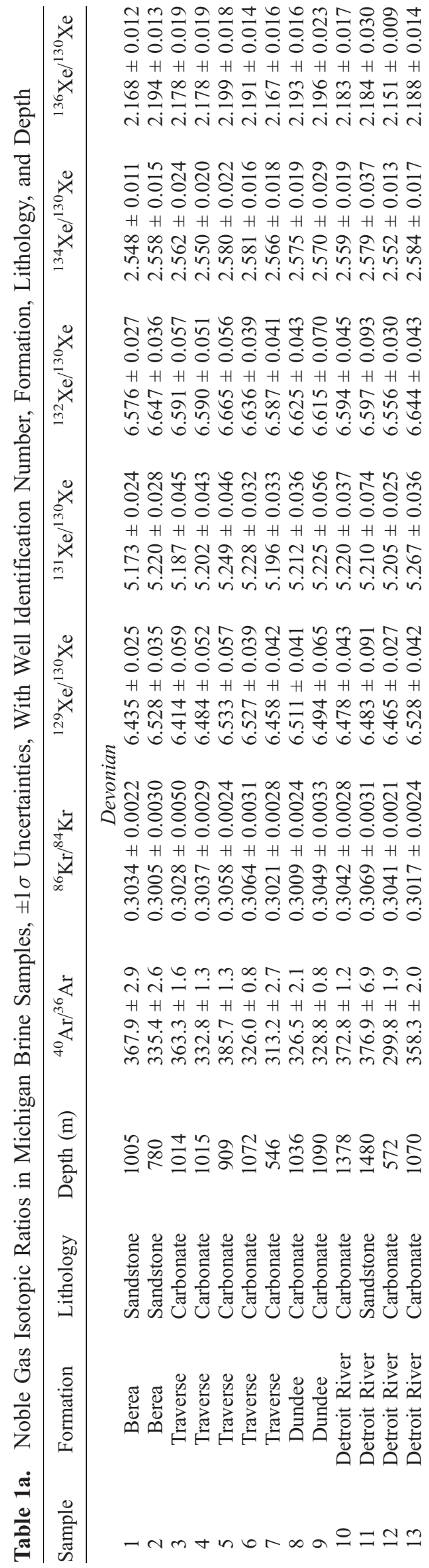

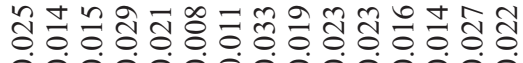

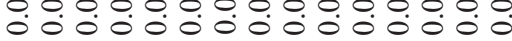
H H H H H H H H H H H H H H H

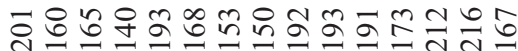
तु

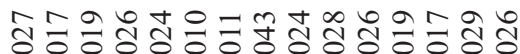
0.00000000000000 H H H H H H H H H H H H H H H

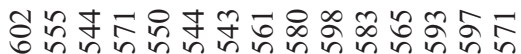
4isisisisisisisici

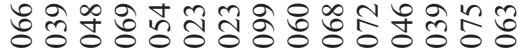
0.000000000000000 H H H H H H H H H H H H H H H

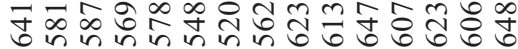
由.

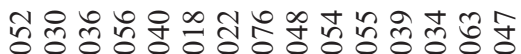
0.0000000 .000000$. H H H H H H H H H H H H H H H

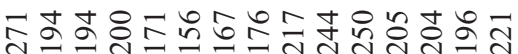

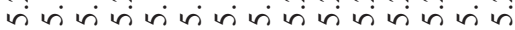

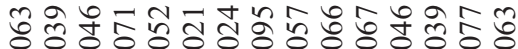
000000000000000 H H H H H H H H H H H H H H H

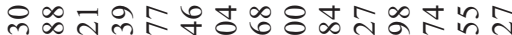

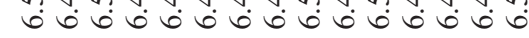
हิ

3

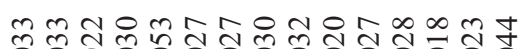
808808888808808 $\circ 00000000000000$

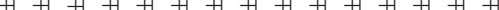

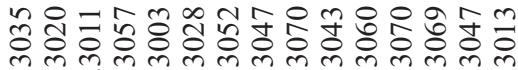
000000000000000

mm $\mathrm{H} H+H+H+H+H+H+H+H+H$

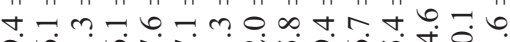

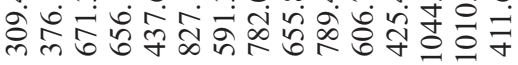

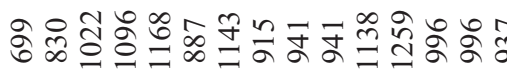

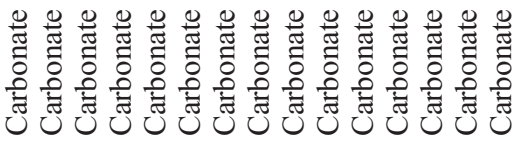

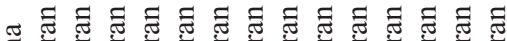

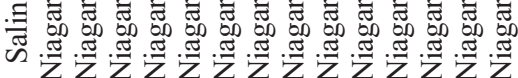

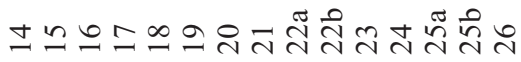

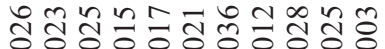
00000000000 H H H H H H H H H H H

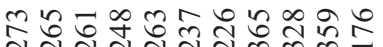

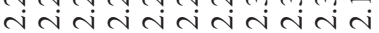

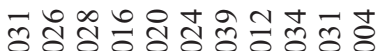
00000000000 H H H H H H H H H H H

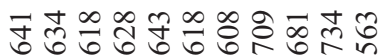
4ivicisicici

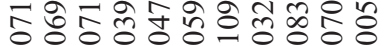
00000000000 H H H H H H H H H H H के

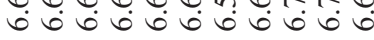

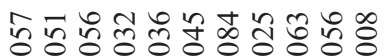
000000000000 H H H H H H H H H H H

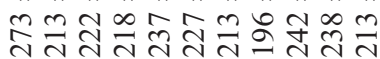

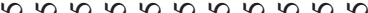

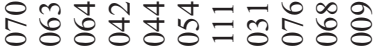
00000000000 H H H H H H H H H H H

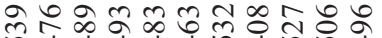

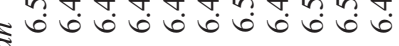

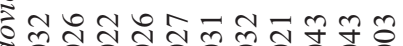
888080888880 0000000000 $H+H+H$ H H H H H H H H

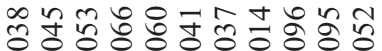

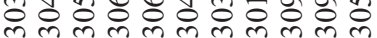
00000000000

rna $\mathrm{H}+\mathrm{H} H \mathrm{H} H \mathrm{H}+\mathrm{H}+$ $\begin{array}{llll}H & H \\ H\end{array}$

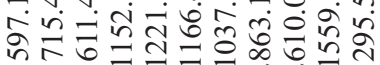
n

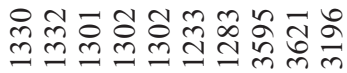

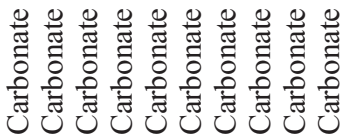

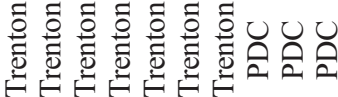

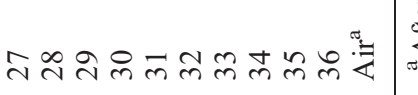


Table 1b. Noble Gas Concentrations of Seawater and Brine at $25^{\circ} \mathrm{C}$

\begin{tabular}{lccr}
\hline & ${ }^{36} \mathrm{Ar}\left(\mathrm{cm}^{3} \mathrm{STP} / \mathrm{g}\right)$ & ${ }^{84} \mathrm{Kr}\left(\mathrm{cm}^{3} \mathrm{STP} / \mathrm{g}\right)$ & ${ }^{130} \mathrm{Xe}\left(\mathrm{cm}^{3} \mathrm{STP} / \mathrm{g}\right)$ \\
\hline Seawater $(0.6 \mathrm{MNaCl}$ solution $)$ at $25^{\circ} \mathrm{C}^{\mathrm{a}}$ & $7.7 \mathrm{E}-7$ & $2.9 \mathrm{E}-8$ & $2.6 \mathrm{E}-10$ \\
Brine $\left(5 \mathrm{MNaCl}\right.$ solution) at $25^{\circ} \mathrm{C}^{\mathrm{a}}$ & $1.8 \mathrm{E}-7$ & $6.0 \mathrm{E}-9$ & $4.9 \mathrm{E}-11$ \\
\hline
\end{tabular}

${ }^{a}$ ASW concentrations calculated from Crovetto et al. [1982], Smith [1985], and Smith and Kennedy [1983].

presence of crustal and/or mantle Xe components in these brines, in addition to the atmospheric component. The presence of mantle Xe could be readily identified through a positive correlation between ${ }^{136} \mathrm{Xe} /{ }^{130} \mathrm{Xe}$ and ${ }^{129} \mathrm{Xe} /{ }^{130} \mathrm{Xe}$ ratios (e.g., blue line, Figure 3a) [after Ozima and Podosek, 2002]. However, most of our Michigan brines do not display such a correlation and plot instead on the crustally produced Xe line (red line, Figure 3a). This suggests that Xe excesses originate largely from a crustal $\mathrm{Xe}$ source. Indeed, ${ }^{136} \mathrm{Xe} /{ }^{130} \mathrm{Xe}$ and ${ }^{134} \mathrm{Xe} /{ }^{130} \mathrm{Xe}$ ratios of Michigan brines display a strong linear correlation $\left(\mathrm{R}^{2}=0.92\right)$ with a slope of 1.2 (Figure $3 \mathrm{~b}$ ), a value that is consistent with the expected ${ }^{136} \mathrm{Xe}^{*} /{ }^{134} \mathrm{Xe}^{*}$ production value from ${ }^{238} \mathrm{U}$ spontaneous fission [e.g., Wetherill, 1953; Eikenberg et al., 1993]. Linear correlations are similarly observed between ${ }^{136} \mathrm{Xe} /{ }^{130} \mathrm{Xe}$ and ${ }^{132} \mathrm{Xe} /{ }^{130} \mathrm{Xe}$ as well as ${ }^{136} \mathrm{Xe} /{ }^{130} \mathrm{Xe}$ and ${ }^{131} \mathrm{Xe} /{ }^{130} \mathrm{Xe}$ ratios, with slopes that are consistent with the respective expected production ratios from ${ }^{238} \mathrm{U}$ spontaneous fission [e.g., Wetherill, 1953; Eikenberg et al., 1993]. On the basis of the above observations, Xe excesses in the Michigan Basin brines have a largely crustal Xe contribution. The positive correlation observed between ${ }^{136} \mathrm{Xe} /{ }^{130} \mathrm{Xe}$ and ${ }^{40} \mathrm{Ar} /{ }^{36} \mathrm{Ar}$ ratios in these brines (Figures $2 \mathrm{c}$ and 2d) further reinforces the notion that a crustal source is also largely responsible for the observed ${ }^{40} \mathrm{Ar}$ excesses.

[17] It is relevant to note upfront that, unlike $\mathrm{Ar}$ and $\mathrm{Xe}$ isotopic ratios (Figures $2 \mathrm{c}$ and $2 \mathrm{~d}$ ), neither $\mathrm{R} / \mathrm{Ra}$ nor ${ }^{21} \mathrm{Ne} /{ }^{22} \mathrm{Ne}$ ratios of Michigan Basin brines display the presence of a vertical gradient along the sedimentary strata (Figures $2 \mathrm{a}$ and $2 \mathrm{~b}$ ).

\subsection{Separation of Crustal Noble Gas Components in Michigan Brines}

[18] Concentrations and elemental ratios of crustally produced noble gases in Michigan Basin brines are reported in Table 2. Crustal He concentrations $\left({ }^{4} \mathrm{He}_{\text {crust }}\right)$ in these brines were estimated by using the $\mathrm{He}$ isotopic ratios as discussed in the previous section. Similarly, crustal ${ }^{21} \mathrm{Ne}$ contributions $\left({ }^{21} \mathrm{Ne}_{\text {crust }}\right)$ were obtained from the analysis of $\mathrm{Ne}$ isotopic ratios [see Castro et al., 2009]. Because crustal $\mathrm{Ar}$ and $\mathrm{Xe}$ excesses are largely dominant and their mantle end-members ill defined, we consider in this study that addition of both ${ }^{40} \mathrm{Ar}$ and ${ }^{136} \mathrm{Xe}$ results in its entirety from crustal production. Crustal Ar and Xe contributions $\left({ }^{40} \mathrm{Ar}_{\text {crust }}\right.$ and $\left.{ }^{136} \mathrm{Xe}_{\text {crust }}\right)$ were thus estimated as follows:

$$
\left({ }^{40} A r_{\text {crust }}\right)=\left({ }^{36} A r\right)_{\text {measured }} \times\left(\left(\frac{{ }^{40} A r}{36 A r}\right)_{\text {measured }}-\left(\frac{{ }^{40} A r}{36 A r}\right)_{\text {air }}\right)
$$

$$
\left({ }^{136} X e_{\text {crust }}\right)=\left({ }^{130} \mathrm{Xe}\right)_{\text {measured }} \times\left(\left(\frac{{ }^{136} \mathrm{Xe}}{{ }^{130} \mathrm{Xe}}\right)_{\text {measured }}-\left(\frac{{ }^{136} \mathrm{Xe}}{{ }^{130} \mathrm{Xe}}\right)_{\text {air }}\right)
$$

where $\left({ }^{40} \mathrm{Ar} /{ }^{36} \mathrm{Ar}\right)_{\text {air }}=295.5$ and $\left({ }^{136} \mathrm{Xe} /{ }^{130} \mathrm{Xe}\right)$ air $=$ 2.176 [Ozima and Podosek, 2002]. Measured ${ }^{36} \mathrm{Ar}$ and ${ }^{130} \mathrm{Xe}$ concentrations were previously reported [Ma et al., 2009]. Neglecting the presence of a potentially small mantle Ar and/or Xe contribution would not affect the discussion and conclusions that follow.

[19] Both ${ }^{4} \mathrm{He}_{\text {crust }}$ and ${ }^{21} \mathrm{Ne}_{\text {crust }}$ concentrations vary over several orders of magnitude, from $1.34 \times$ $10^{-7}$ to $1.69 \times 10^{-3} \mathrm{~cm}^{3} \mathrm{STP} / \mathrm{g}$ and from $1.03 \times$ $10^{-14}$ to $2.97 \times 10^{-11} \mathrm{~cm}^{3} \mathrm{STP} / \mathrm{g}$, respectively and they display an absence of vertical concentration gradients along the sedimentary strata (Table 2). By contrast, the presence of a vertical gradient for ${ }^{40} \mathrm{Ar}_{\text {crust }}$ and ${ }^{136} \mathrm{Xe}_{\text {crust }}$ concentrations in the Michigan brines, which range from $1.18 \times 10^{-7}$ to $4.70 \times 10^{-5} \mathrm{~cm}^{3} \mathrm{STP} / \mathrm{g}$ and $1.09 \times 10^{-14}$ to

Figure 2. Noble gas isotopic ratios of Michigan Basin brines in the sedimentary sequence. (a) R/Ra ratios [Castro et al., 2009], where gray areas indicate the typical crustal $\mathrm{R} / \mathrm{Ra}$ values $(\sim 0.01-0.05)$ [Oxburgh et al., 1986] and mantle (mid-ocean ridge basalts (MORB)) R/Ra values ( $>\sim 8$ [Graham, 2002]); (b) ${ }^{21} \mathrm{Ne} /{ }^{22} \mathrm{Ne}$ ratios [Castro et al., 2009]; (c) ${ }^{40} \mathrm{Ar} /{ }^{36} \mathrm{Ar}$ ratios; and (d) ${ }^{136} \mathrm{Xe} /{ }^{130} \mathrm{Xe}$ ratios. The isotopic ratios of air (blue dashed lines) are shown [Ozima and Podosek, 2002] for all ratios except for $\mathrm{R} / \mathrm{Ra}$ as $\mathrm{He}$ atmospheric contributions are negligible in these samples. 

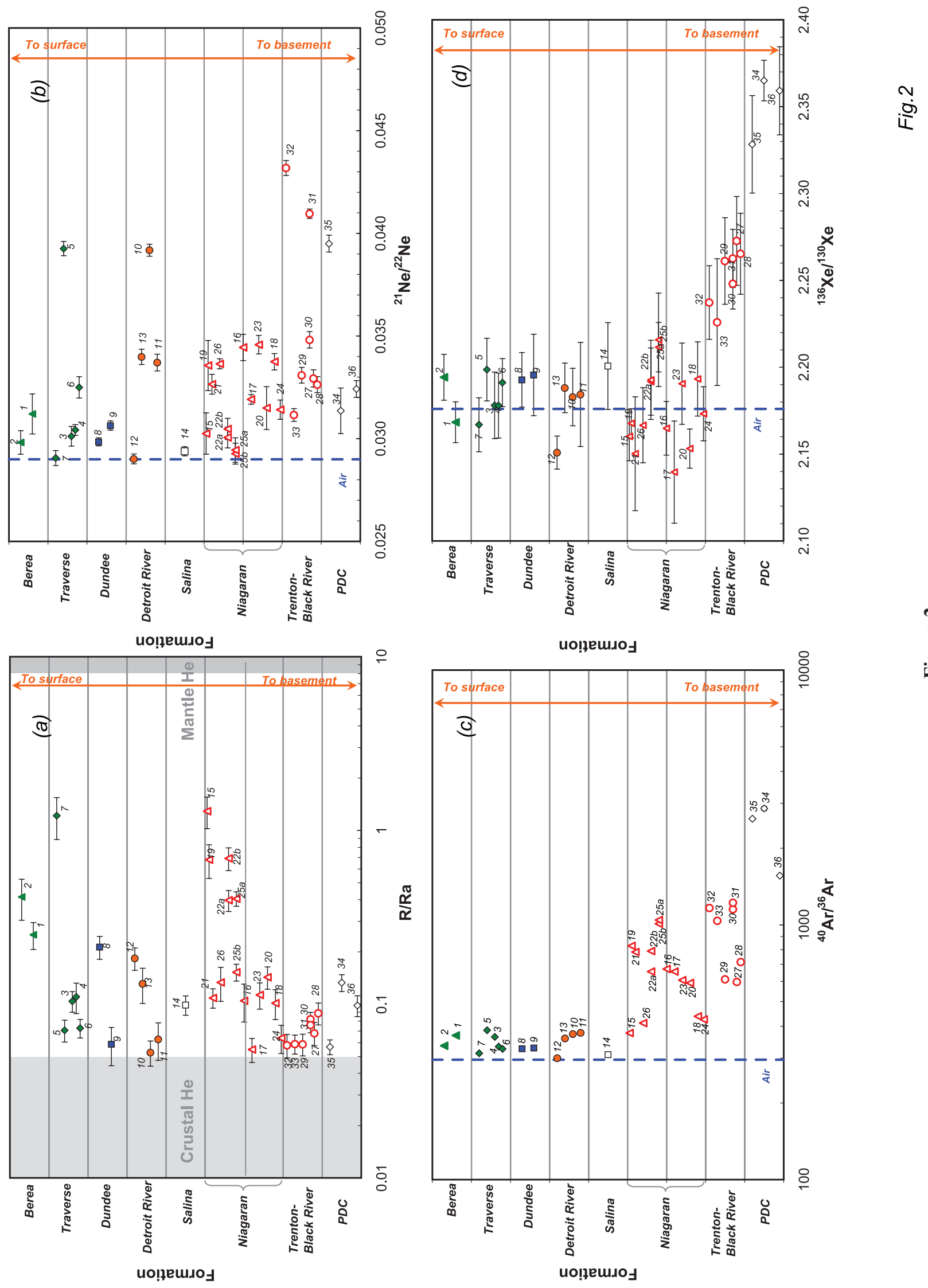

ํㅣㄹ 

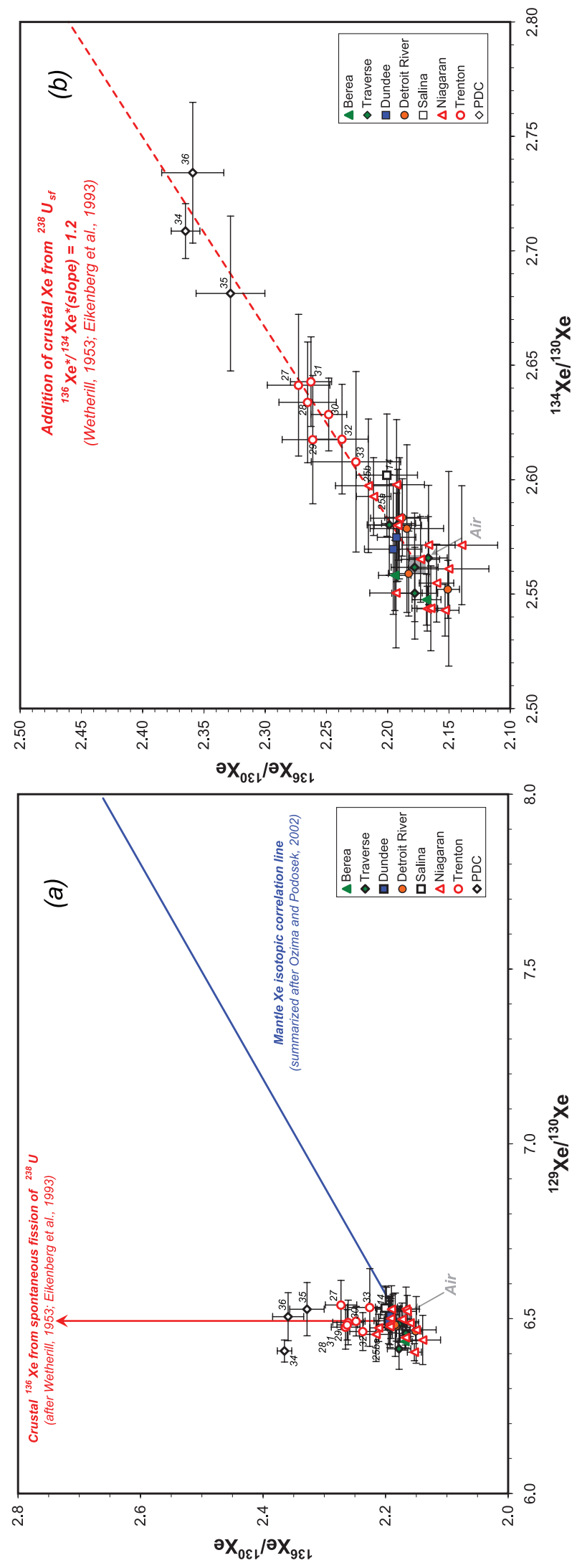

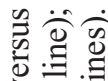

$>=\exists$

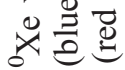

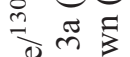

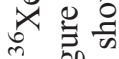

อิ 焉

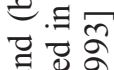

0 .

$x \cdot \frac{0}{3} \dot{0}$

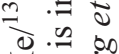

는

ป :

क人

क्षे

$x: 2$

每

ब

ำ

สరิ

$\ddot{\otimes}$ 过

园

$\exists 0$

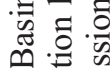

总

쿵

$\sum$

.

象

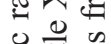

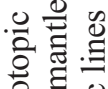

을

记

这.

mio $x$

紫焉 


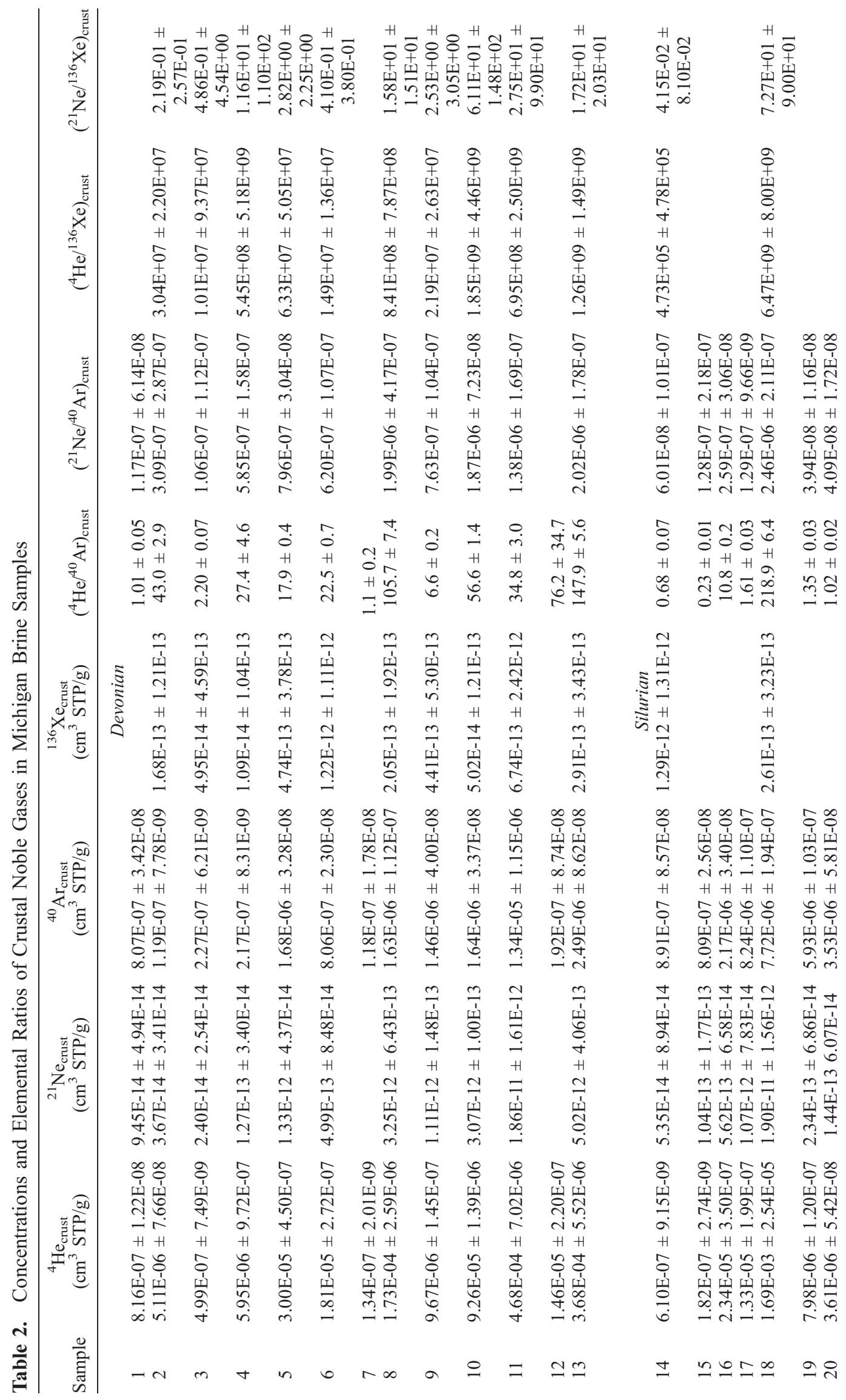


$1.54 \times 10^{-11} \mathrm{~cm}^{3} \mathrm{STP} / \mathrm{g}$, respectively (Table 2 ) is apparent. Light $\left({ }^{4} \mathrm{He}\right.$ and $\left.{ }^{21} \mathrm{Ne}\right)$ and heavy (e.g., ${ }^{40} \mathrm{Ar}$ and ${ }^{136} \mathrm{Xe}$ ) noble gases thus display fundamentally different patterns within the basin.

\section{Discussion}

[20] In the previous section we have clearly shown the occurrence of crustal noble gases in all Michigan brines. We have also shown that unlike ${ }^{4} \mathrm{He}_{\text {crust }}$ and ${ }^{21} \mathrm{Ne}_{\text {crust }}$, both ${ }^{40} \mathrm{Ar}_{\text {crust }}$ and ${ }^{136} \mathrm{Xe}_{\text {crust }}$ display the presence of a strong vertical gradient along the sedimentary sequence, pointing to their deep origin (Figure 2). Here, we will first show that most crustally produced noble gases likely originate in the Precambrian basement rocks. We will then discuss the observed distribution patterns of elemental ratios along the sedimentary strata and potential mechanisms of upward vertical transport within the basin through a simple Rayleigh-type fractionation model. Finally we will discuss the implications for the thermal evolution history in this currently stable region.

\subsection{Precambrian Basement Rocks as an External Source for Crustally Produced Noble Gases in Michigan Basin Brines}

[21] The amount of crustally produced noble gases released into groundwater depends mainly on three factors: (1) production rate in the crustal rock, (2) efficiency of the isotope released from the rock into the water, and (3) duration of the rock-fluid interaction. Concentration of crustal noble gases into the water can thus be estimated following:

$$
\left[C_{i}\right]_{H_{2} O}=P_{i} \times \rho_{r} / \rho_{w} \times \Lambda \times((1-\omega) / \omega) \times t
$$

where $\left[C_{i}\right]_{H 2 O}$ is the concentration of the isotope $i$ accumulated in the water $\left(\mathrm{cm}^{3} \mathrm{STPg}^{-1} \mathrm{H}_{2} \mathrm{O}\right) ; P_{i}$ is the crustal production rate of isotope $i$ in the reservoir rock $\left(\mathrm{cm}^{3} \mathrm{STPg} \mathrm{g}_{\text {rock }}^{-1} \mathrm{yr}^{-1}\right), \rho_{r}$ is the density of the rock $\left(2.6 \mathrm{~g} \mathrm{~cm}^{-3}\right), \rho_{w}$ is the density of the water $\left(1 \mathrm{~g} \mathrm{~cm}^{-3}\right), \Lambda$ is the release efficiency from the rock matrix into water (normally assumed to be unity), $\omega$ is the porosity of the reservoir rock, and $t$ is the residence time of the water (years).

[22] Crustal noble gas production rates $\left(P_{i}\right)$ can be estimated from $\mathrm{U}, \mathrm{Th}, \mathrm{K}$, and major element concentrations of reservoir rocks as summarized by Ballentine and Burnard [2002]. Production rates of individual sampled formations in this study (Figure 1b), the underlying Precambrian crystalline basement, as well as the average upper crust were calculated and are listed in Table 3.

[23] The existence of an external source for the crustal noble gases in these brines can be demonstrated by using a simple first-order calculation of ${ }^{40} \mathrm{Ar} /{ }^{36} \mathrm{Ar}$ and ${ }^{136} \mathrm{Xe} /{ }^{130} \mathrm{Xe}$ ratios in the water phase using ${ }^{40} \mathrm{Ar}$ and ${ }^{136} \mathrm{Xe}$ production rates (Table 3 ). In this study, Ordovician PDC carbonates are the deepest and the oldest formation $(\sim 10 \%$ porosity [Dolton, 1995]). Assuming that in situ produced ${ }^{40} \mathrm{Ar}$ and ${ }^{136} \mathrm{Xe}$ in the $480 \mathrm{Ma}$ carbonates were entirely released into the water phase (with initial noble gas concentrations corresponding to that of seawater at $25^{\circ} \mathrm{C}$ (Table 1b) [Ozima and Podosek, 2002]), the resultant ${ }^{40} \mathrm{Ar} /{ }^{36} \mathrm{Ar}$ and ${ }^{136} \mathrm{Xe} /{ }^{130} \mathrm{Xe}$ ratios in the water phase would be 448 and 2.235, respectively, both significantly lower than the measured ${ }^{40} \mathrm{Ar} /{ }^{36} \mathrm{Ar}$ and ${ }^{136} \mathrm{Xe} /{ }^{130} \mathrm{Xe}$ ratios in the PDC brines (up to $2863.1 \pm 55.5$ and $2.365 \pm 0.012$, respectively; Table 1a). In fact, the total in situ produced ${ }^{40} \mathrm{Ar}$ and ${ }^{136} \mathrm{Xe}$ within the 480 Ma carbonates can only account for about $6 \%$ and $30 \%$ of the total observed ${ }^{40} \mathrm{Ar}$ and ${ }^{136} \mathrm{Xe}$ excesses, respectively. Therefore, this strongly suggests that these brines received crustal noble gases from a source external to their sedimentary reservoirs, most likely from the underlying Precambrian crystalline basement, which is capable of producing significant amounts of crustal noble gases because of its much greater age $(\sim 1.1$ to greater than $2.5 \mathrm{Ga})$ and high $\mathrm{U}, \mathrm{Th}$, and $\mathrm{K}$ content (Table 3 ). Indeed, the involvement of the Precambrian basement in the crustal noble gas mass balance is also supported by the observed high He excesses in the shallow Marshall aquifer, which requires an unusually high $\mathrm{He}$ flux from below, partly supplied by the sedimentary formations and partly from the deep Precambrian basement (Figure 1b) [Ma et al., 2005]. Deep external sources that account for crustal noble gas excesses have also been previously proposed [e.g., Torgersen and Clarke, 1985; Zaikowski et al., 1987; Torgersen et al., 1989; Ballentine et al., 1996; Castro et al., 1998a, 1998b; Kulongoski et al., 2005].

[24] Alternatively, if one would consider initial noble gas concentrations corresponding to that of brines ( $5 \mathrm{M} \mathrm{NaCl}$ solution) at $25^{\circ} \mathrm{C}$ (Table $\left.1 \mathrm{~b}\right)$ and a production time elapsed since the major thermal event, i.e., $\sim 111 \mathrm{Ma}$ [see., e.g., Castro et al., 2009], the resultant ${ }^{40} \mathrm{Ar} /{ }^{36} \mathrm{Ar}$ and ${ }^{136} \mathrm{Xe} /{ }^{130} \mathrm{Xe}$ ratios in the water phase would be 444 and 2.250 , respectively, values that are significantly lower than measured ones. Even then, such calculations assume that all in situ produced noble gases are released into the water phase, a highly unlikely 


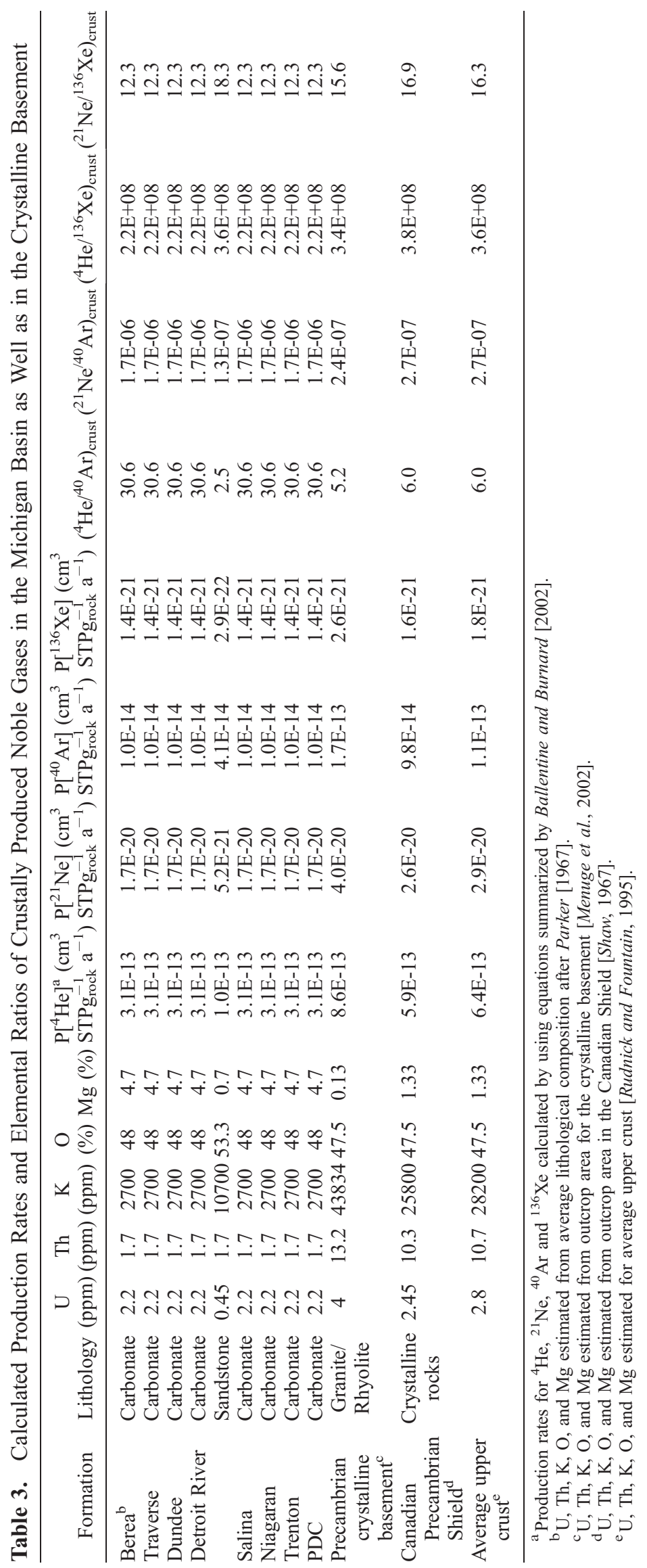


scenario as indicated by their respective release temperatures (see below). We thus conclude, independent of the original water composition, that in situ production is negligible within the basin. Finally, if one considers the measured noble gas concentrations in the Michigan Basin brines (e.g., average values from Ma et al. [2009]) and a production time of $111 \mathrm{Ma}$, the resultant ${ }^{40} \mathrm{Ar} /{ }^{36} \mathrm{Ar}$ and ${ }^{136} \mathrm{Xe} /{ }^{130} \mathrm{Xe}$ ratios in the water phase are 1231 and 2.268, respectively, values that are also significantly lower than measured ones. Thus, the last scenario reinforces the conclusion that in situ production is negligible within the basin.

[25] Rock release temperatures required for noble gases also strongly favor an external origin for most crustally produced noble gases in the Michigan Basin. Indeed, it is generally accepted that release of crustal noble gases from individual minerals is dependent on their closure temperatures which are inversely correlated to the noble gas diffusivity in these minerals [Dodson, 1973]. For instance, while radiogenic ${ }^{4} \mathrm{He}$ is released from calcite for aquifer temperatures above $50-70^{\circ} \mathrm{C}$ [Copeland et al., 2007], release temperatures for radiogenic ${ }^{40} \mathrm{Ar}$ in common K-bearing minerals (e.g., muscovite, K-feldspar) are much higher, above $\sim 250-275^{\circ} \mathrm{C}$ [Lippolt and Weigel, 1988]. Although release temperatures for $\mathrm{Ne}$ and $\mathrm{Xe}$ in these common minerals are currently uncertain, on the basis of their diffusivity decrease with increasing atomic numbers [Ozima and Podosek, 2002], it is reasonable to assume that $\mathrm{Ne}$ release temperatures will fall between those of $\mathrm{He}$ and $\mathrm{Ar}$ (e.g., $\sim 70-250^{\circ} \mathrm{C}$ ), while $\mathrm{Xe}$ release temperatures are expected to be greater than those of $\mathrm{Ar}$ (e.g., $>275^{\circ} \mathrm{C}$ ). These assumptions are supported by the increasing release temperatures for ${ }^{4} \mathrm{He},{ }^{21} \mathrm{Ne},{ }^{84} \mathrm{Kr}$, and ${ }^{136} \mathrm{Xe}$ in zircons [Honda et al., 2004; Gautheron et al., 2006], as well as the observed Xe release temperature in meteorites, which was shown to be greater than that of Ar [Burkland et al., 1995]. Because of its currently low geothermal gradient $\left(\sim 19^{\circ} \mathrm{C} / \mathrm{km}\right)$ [Vugrinovich, 1989], fluid temperatures in most of our sampled formations in the Michigan Basin are $\sim 40-80^{\circ} \mathrm{C}$, far lower than release temperatures required for ${ }^{40} \mathrm{Ar}$ and ${ }^{136} \mathrm{Xe}$. It is thus apparent that only the Precambrian crystalline basement can account for most of the measured crustally produced noble gases in the Michigan Basin.

[26] The existence of an external source is further supported by the presence of mantle $\mathrm{He}$ and $\mathrm{Ne}$ previously identified in these same brines and released during a past thermal event [Castro et al., 2009]. Such a mantle component also points to the presence of an upward transport process during which both crustal and mantle noble gases were released into the basin via deep-seated faults and fractures from the underlying basement and lithospheric mantle.

\subsection{Elemental Fractionation Patterns of Crustally Produced Noble Gases in Michigan Brines}

[27] Crustally produced noble gases released at great depths and high temperatures are expected to have elemental ratios close to their crustal production ratios, as frequently observed in deep fluids from many other sedimentary basins around the world, for example, the Paris Basin [Pinti and Marty, 1995; Castro et al., 1998a], the Great Artesian Basin [Torgersen et al., 1989], and the Pannonian Basin [Ballentine et al., 1991]. In the Michigan Basin, ${ }^{4} \mathrm{He} /{ }^{40} \mathrm{Ar}$ production ratios within the crystalline basement are estimated to be $\sim 5.2-$ 6.0 (Table 3). These values are very similar to the average upper crustal production value $\left({ }^{4} \mathrm{He} /{ }^{40} \mathrm{Ar}\right.$ : $\sim 6.0$; Table 3). $\left({ }^{4} \mathrm{He} /{ }^{40} \mathrm{Ar}\right)_{\text {crust }}$ ratios in our brine samples vary over several orders of magnitude with values between $\sim 0.045$, far smaller than the crustal production ratio and 218.9 , much greater than crustal production ratio (Table 2$).\left({ }^{21} \mathrm{Ne} /{ }^{40} \mathrm{Ar}\right)_{\text {crust }}$ also varies over several orders of magnitude with values between $1.81 \times 10^{-9}$ and $2.46 \times 10^{-6}$ (Table 2), as compared to the crustal production ratio $\left(2.7 \times 10^{-7}\right.$; Table 3$) .\left({ }^{4} \mathrm{He} /{ }^{136} \mathrm{Xe}\right)_{\text {crust }}$ and $\left({ }^{21} \mathrm{Ne} /{ }^{136} \mathrm{Xe}\right)_{\text {crust }}$ elemental ratios also show a similar pattern, with values varying from $7.40 \times 10^{4}$ to $6.47 \times 10^{9}$ and 0.00554 to 72.7 , respectively (Table 2), far different from their production ratios of $3.8 \times 10^{8}$ and 16.9 (Table 3 ).

[28] $\left({ }^{4} \mathrm{He} /{ }^{40} \mathrm{Ar}\right)_{\text {crust }}$ and $\left({ }^{21} \mathrm{Ne} /{ }^{40} \mathrm{Ar}\right)_{\text {crust }}$ ratios in these brines display a similar, very specific and interesting pattern (Figures $4 \mathrm{a}$ and $4 \mathrm{~b}$ ), in addition to presenting a strong positive correlation (Figure 5a). Indeed, with the exception of a few samples (e.g., samples 26 and 18), samples from the deeper formations (e.g., Salina, Niagaran, Trenton and PDC) display elemental ratios smaller than (or close to) the expected crystalline basement production ratios. By contrast, with the exception of samples 1 , 3 , and 7, all other samples in the shallower formations (i.e., Berea, Traverse, Dundee, and Detroit River) display ratios that are greater (or far greater) than the production ratios (Figures $4 \mathrm{a}$ and $4 \mathrm{~b}$ ). A general trend is thus apparent in which samples 


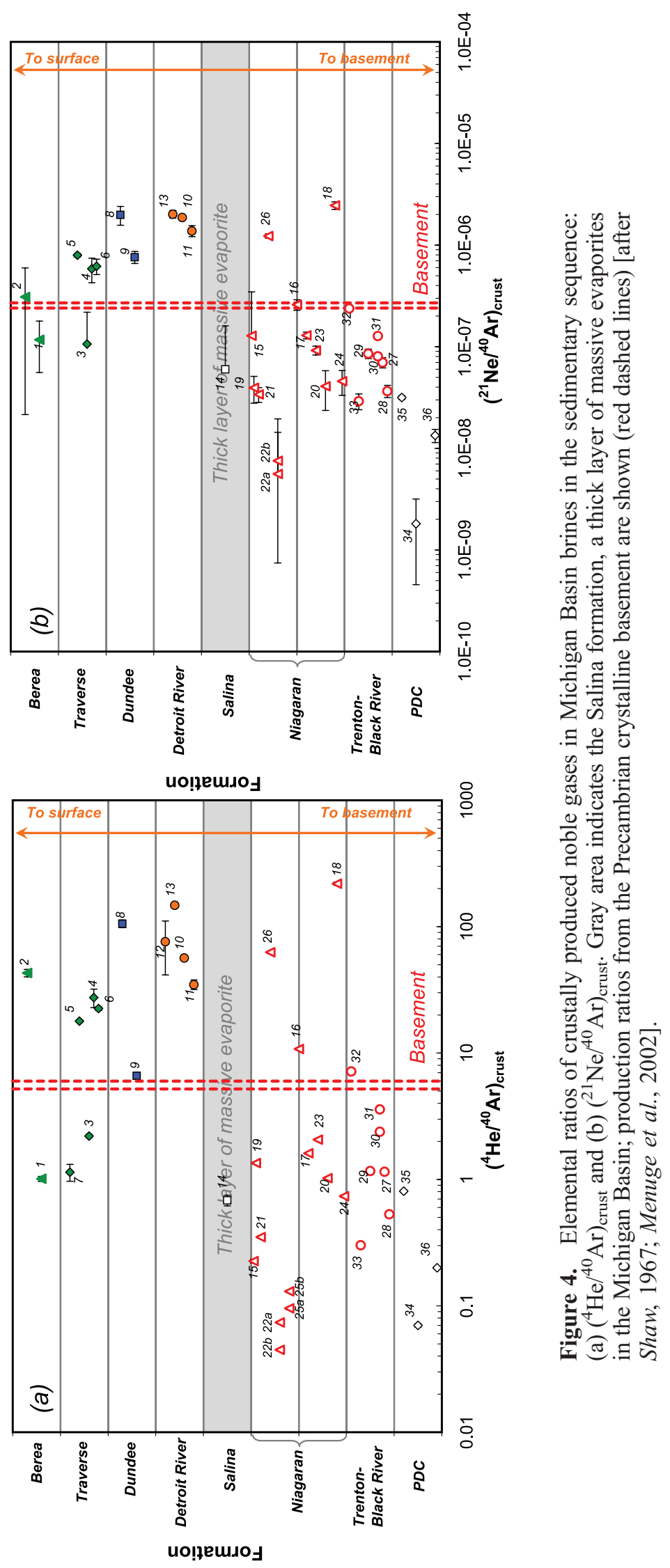



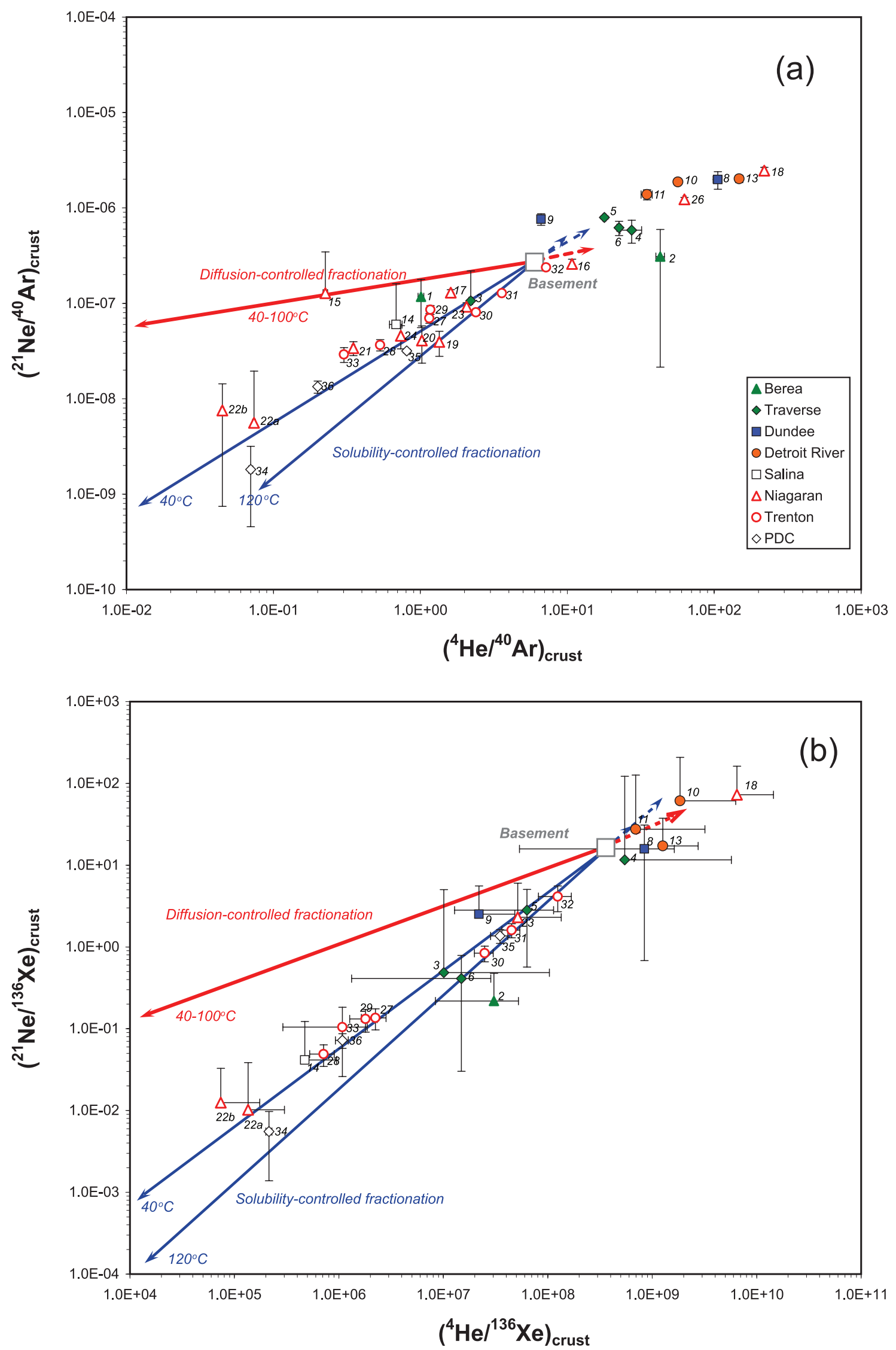

Figure 5 
from the shallower formations display elemental ratios complementary to those of deep formations, separated by the Salina formation (Figure 1b), an extremely thick sequence composed mostly of massive evaporites [Catacosinos et al., 1991]. Similar patterns are observed for $\left({ }^{4} \mathrm{He} /{ }^{136} \mathrm{Xe}\right)_{\text {crust }}$ and $\left({ }^{21} \mathrm{Ne} /{ }^{136} \mathrm{Xe}\right)$ crust ratios (Table 3 and Figure $5 b)$. These results show that samples above the Salina Group (shallow formations) are relatively enriched (in some cases to a great extent) in ${ }^{4} \mathrm{He}_{\text {crust }}$ and ${ }^{21} \mathrm{Ne}_{\text {crust }}$ with respect to ${ }^{40} \mathrm{Ar}_{\text {crust }}$ and ${ }^{136} \mathrm{Xe}_{\text {crust }}$, as opposed to those below the massive evaporite layer (deeper formations) which exhibit complementary patterns (Figures 4 and 5).

[29] It was previously suggested that crustal fluids released in a low-temperature environment (e.g., $50-250^{\circ} \mathrm{C}$ ) may present ${ }^{4} \mathrm{He} /{ }^{40} \mathrm{Ar}$ ratios greater than the production ratio because of their different release temperatures [O'Nions and Ballentine, 1993]. However, such a low-temperature source could not explain either the observed $\left({ }^{4} \mathrm{He} /{ }^{40} \mathrm{Ar}\right)_{\text {crust }}$ ratios in our basin brines (much lower than the production ratio), or the observed systematic patterns within the sedimentary strata. Furthermore, it is apparent, as discussed above, that crustal noble gases in the Michigan Basin were not released in a low-temperature environment. Various production ratios due to different lithologies in the basin (e.g., ${ }^{4} \mathrm{He} /{ }^{40} \mathrm{Ar}$ ratio $\sim 2.5-30$; Table 4 ) can also be ruled out as these cannot account for the observed extremely large range of variations in the elemental ratios (Table 2). Alternatively, it has been shown that preferential upward transport of $\mathrm{He}$ and $\mathrm{Ne}$ by diffusion in groundwater can lead to a relative enrichment of these gases with respect to $\mathrm{Ar}$ [Castro et al., 1998a, 1998b]. As shown by Castro et al. [1998a, 1998b], such preferential transport and subsequent relative enrichment of $\mathrm{He}$ and $\mathrm{Ne}$ is due to their higher diffusion coefficients with respect to Ar [Wise and Houghton, 1966, 1968; Ohsumi and Horibe, 1984; Jähne et al., 1987]. The extent of this enrichment will also greatly depend on their concentration gradients which are typically greater for $\mathrm{He}$ with respect to $\mathrm{Ne}$, thus, leading to a greater level of He enrichment. Here, we suggest a possible mechanism involving the upward transport of deep crustal noble gases from basement rocks toward the surface in which both high $\mathrm{He}$ and $\mathrm{Ne}$ diffusivities, combined with solubilitycontrolled processes that might occur when a gas phase (e.g., $\mathrm{CO}_{2}$ or $\mathrm{CH}_{4}$ ) is present [Zartman et al., 1961; Bosch and Mazor, 1988] might lead to the observed fractionation between $\mathrm{He}, \mathrm{Ne}$ and Ar, Xe. For elemental fractionation controlled by either diffusion or solubility processes, fluids in the upper portion of the sedimentary sequence are expected to be enriched in ${ }^{4} \mathrm{He}$ and ${ }^{21} \mathrm{Ne}$ as they are subjected to the additional arrival of ${ }^{4} \mathrm{He}$ and ${ }^{21} \mathrm{Ne}$ with respect to ${ }^{40} \mathrm{Ar}$ and ${ }^{136} \mathrm{Xe}$ from below, while the fluids in lower formations will show a relative enrichment of ${ }^{40} \mathrm{Ar}$ and ${ }^{136} \mathrm{Xe}$ resulting from a more marked loss of ${ }^{4} \mathrm{He}$ and ${ }^{21} \mathrm{Ne}$. This is precisely the observed pattern in our brine samples (Figures 4 and 5). In the following section, a simple Rayleigh-type elemental fractionation model is used to test this hypothesis and to better constrain processes leading to the observed elemental fractionation during upward transport.

\subsection{Mechanisms for the Observed Noble Gas Elemental Fractionation: A Rayleigh- Type Elemental Fractionation Model}

[30] As previously discussed, the observed elemental fractionation might be due to either diffusioncontrolled or solubility-controlled processes during upward transport of crustal noble gases in the basin. To test this hypothesis, we use a simple model in which fractionated elemental ratios in the escaped phase (into the shallow formations) and in the retained phase (left in the deep formations) can be simulated during upward transport using the Rayleigh Law as follows:

$$
\begin{aligned}
& \left(\frac{{ }^{4} \mathrm{He}}{{ }^{40} \mathrm{Ar}}\right)_{\text {retained }}=\left(\frac{{ }^{4} \mathrm{He}}{40 \mathrm{Ar}}\right)_{0} f^{(\alpha-1)} \\
& \left(\frac{{ }^{4} \mathrm{He}}{{ }^{40} \mathrm{Ar}}\right)_{\text {escaped }}=\left(\frac{{ }^{4} \mathrm{He}}{{ }^{40} \mathrm{Ar}}\right)_{0} \frac{1-f^{\alpha}}{1-f}
\end{aligned}
$$

where subscripts 0 , retained, and escaped stand for elemental ratios in the initial, retained, and escaped phases, respectively; $f$ is the fraction of ${ }^{40} \mathrm{Ar}$ remaining in the retained phase after fractionation

Figure 5. Elemental ratios of crustally produced noble gases in Michigan Basin brines: (a) $\left({ }^{4} \mathrm{He} /{ }^{40} \mathrm{Ar}\right)_{\text {crust }}$ and $\left({ }^{21} \mathrm{Ne} /{ }^{40} \mathrm{Ar}\right)_{\text {crust }}$ ratios and (b) $\left({ }^{4} \mathrm{He} /{ }^{136} \mathrm{Xe}\right)_{\text {crust }}$ and $\left({ }^{21} \mathrm{Ne} /{ }^{136} \mathrm{Xe}\right)_{\text {crust }}$ ratios. Production ratios from the Precambrian crystalline basement are shown (open square) [after Shaw, 1967; Menuge et al., 2002]. Elemental fractionation trends are calculated using a simple Rayleigh-type fractionation model for a diffusion-controlled process (at $\left.40-100^{\circ} \mathrm{C}\right)(\mathrm{red}$ line) and a solubility-controlled process (at $40-120^{\circ} \mathrm{C}$ ) (blue lines). Solid and dashed lines indicate the fractionated elemental ratios in the retained and escaped phases, respectively. 
Table 4. Diffusion Coefficient Values and Henry's Law Constants Used in the Rayleigh Model

\begin{tabular}{lcccc}
\hline & $\mathrm{D}$ at $40^{\circ} \mathrm{C}^{\mathrm{a}}\left(\mathrm{cm}^{2} \mathrm{~s}^{-1}\right)$ & $\mathrm{D}$ at $100^{\circ} \mathrm{C}^{\mathrm{a}}\left(\mathrm{cm}^{2} \mathrm{~s}^{-1}\right)$ & $\mathrm{K}$ at $\left.40^{\circ} \mathrm{C}^{\mathrm{b}}(\mathrm{atm} \mathrm{kg} \mathrm{mol})^{-1}\right)$ & $\mathrm{K}$ at $120^{\circ} \mathrm{C}^{\mathrm{b}}\left(\mathrm{atm} \mathrm{kg} \mathrm{mol}^{-1}\right)$ \\
\hline $\mathrm{He}$ & $9.15 \mathrm{E}-05$ & $1.88 \mathrm{E}-04$ & $7.41 \mathrm{E}+03$ & $1.71 \mathrm{E}+03$ \\
$\mathrm{Ne}$ & $5.38 \mathrm{E}-05$ & $1.35 \mathrm{E}-04$ & $7.20 \mathrm{E}+03$ & $1.88 \mathrm{E}+03$ \\
$\mathrm{Ar}$ & $4.09 \mathrm{E}-05$ & $1.19 \mathrm{E}-04$ & $3.51 \mathrm{E}+03$ & $1.10 \mathrm{E}+03$ \\
$\mathrm{Kr}$ & $2.73 \mathrm{E}-05$ & $9.51 \mathrm{E}-05$ & $2.20 \mathrm{E}+03$ & $7.82 \mathrm{E}+02$ \\
$\mathrm{Xe}$ & $2.24 \mathrm{E}-05$ & $8.50 \mathrm{E}-05$ & $1.54 \mathrm{E}+03$ & $5.69 \mathrm{E}+02$ \\
$\alpha(\mathrm{He} / \mathrm{Ar})$ & 2.24 & 1.58 & 2.11 & 1.56 \\
$\alpha(\mathrm{Ne} / \mathrm{Ar})$ & 1.32 & 1.13 & 2.05 & 1.71 \\
$\alpha(\mathrm{He} / \mathrm{Xe})$ & 4.08 & 2.22 & 4.82 & 3.01 \\
$\alpha(\mathrm{Ne} / \mathrm{Xe})$ & 2.40 & 1.58 & 4.69 & 3.30 \\
\hline
\end{tabular}

\footnotetext{
${ }^{\mathrm{a}}$ Diffusion coefficients in water calculated after Jähne et al. [1987].

${ }^{b}$ Henry's Law constants for a $4.4 \mathrm{M} \mathrm{NaCl}$ brine solution calculated after Crovetto et al. [1982], Smith [1985], and Smith and Kennedy [1983]. Because of a lack of solubility data for high temperatures and salinities, Henry's Law constants at $120^{\circ} \mathrm{C}$ are calculated for a freshwater value.
}

occurred. Similar models have been previously used by Battani et al. [2000] and Brennwald et al. [2005] to study noble gas elemental fractionation in natural gas and sediment pore waters, respectively. For a diffusion-controlled process, the exponent coefficient $\alpha$ is given by:

$$
\alpha=\frac{D_{H e}}{D_{A r}}
$$

where $D_{H e}$ and $D_{A r}$ are the noble gas diffusion coefficients in porous media, which can be in turn related to noble gas diffusion coefficients in water [Ohsumi and Horibe, 1984; Jähne et al., 1987]. The exponent coefficient $\alpha$ for a solubilitycontrolled process is given by:

$$
\alpha=\frac{K_{H e}}{K_{A r}}
$$

where $K_{H e}$ and $K_{A r}$ are Henry's Law constants [Crovetto et al., 1982; Smith, 1985; Smith and Kennedy, 1983]. Similar sets of equations can be derived for ${ }^{21} \mathrm{Ne} /{ }^{40} \mathrm{Ar},{ }^{4} \mathrm{He} /{ }^{136} \mathrm{Xe}$, and ${ }^{40} \mathrm{Ar} /{ }^{136} \mathrm{Xe}$ ratios, respectively. Diffusion coefficient values and Henry's Law constants used for all gases are given in Table 4. Both diffusion and solubility coefficients are highly dependent on temperature. However, when applied in the Rayleigh Law equations (equations (4) and (5)), the impact of temperature on the observed fractionation due to a diffusion controlled process almost vanishes because of the similar diffusion coefficient values and similar temperature dependence for $\mathrm{He}$ and $\mathrm{Ne}$.

[31] Elemental fractionation due to both diffusionand solubility-controlled processes under reservoir temperatures of $40-100^{\circ} \mathrm{C}$ and $40-120^{\circ} \mathrm{C}$, respectively, are shown in Figure 5. It is apparent that both processes are capable of producing relative enrichment of light noble gases $\left({ }^{4} \mathrm{He}\right.$ and $\left.{ }^{21} \mathrm{Ne}\right)$ in the escaped phases (dashed lines) and complementary relative enrichment of heavy noble gases $\left({ }^{40} \mathrm{Ar}\right.$ and ${ }^{136} \mathrm{Xe}$ ) in the retained phases (solid lines). It is clear that except for a few samples $(15,1,32$, and 16) that follow the diffusion-controlled fractionation pattern (red line), many brine samples follow closely the solubility-controlled elemental fractionation pattern within a temperature range of 40$120^{\circ} \mathrm{C}$ (blue lines) (Figure 5a). A subset of samples falls between the trends defined by the diffusionand solubility-controlled fractionations. This might represent either a combination of both processes occurring at the same location but separated in time, or simply a mixture between brines whose composition resulted from diffusion- and solubility-controlled fractionation, respectively. Similar patterns are also observed with $\left({ }^{4} \mathrm{He} /{ }^{136} \mathrm{Xe}\right)_{\text {crust }}$ and $\left({ }^{21} \mathrm{Ne} /{ }^{136} \mathrm{Xe}\right)_{\text {crust }}$ (Figure $\left.5 \mathrm{~b}\right)$. We thus suggest that both solubility- and diffusion-controlled mechanisms are responsible for the observed elemental fractionation patterns in these brines. While high diffusivities and preferential concentration in the gas phase of $\mathrm{He}$ and $\mathrm{Ne}$ with respect to $\mathrm{Ar}$ and $\mathrm{Xe}$ lead to a relative enrichment of ${ }^{4} \mathrm{He}$ and ${ }^{21} \mathrm{Ne}$ above the Salina formation during upward transport, relative enrichment of ${ }^{40} \mathrm{Ar}$ and ${ }^{136} \mathrm{Xe}$ is observed below this very low permeability formation, which severely slows upward movement of these two gases (Figures 4 and 5).

[32] Few samples fall outside of this general pattern. For example, samples 26 and 18 in the deep Niagaran formation show signatures similar to those of the shallow formations (e.g., Figure 5a). This may indicate that the escaped phase may sometimes be trapped below the Salina formation. By contrast, the retained phase may also be transported to the shallow formations at a later time and this may explain the unusual signatures of samples 1 and 3 (Figure 5a). These exceptions reflect the complexity of the system considering the spatial 

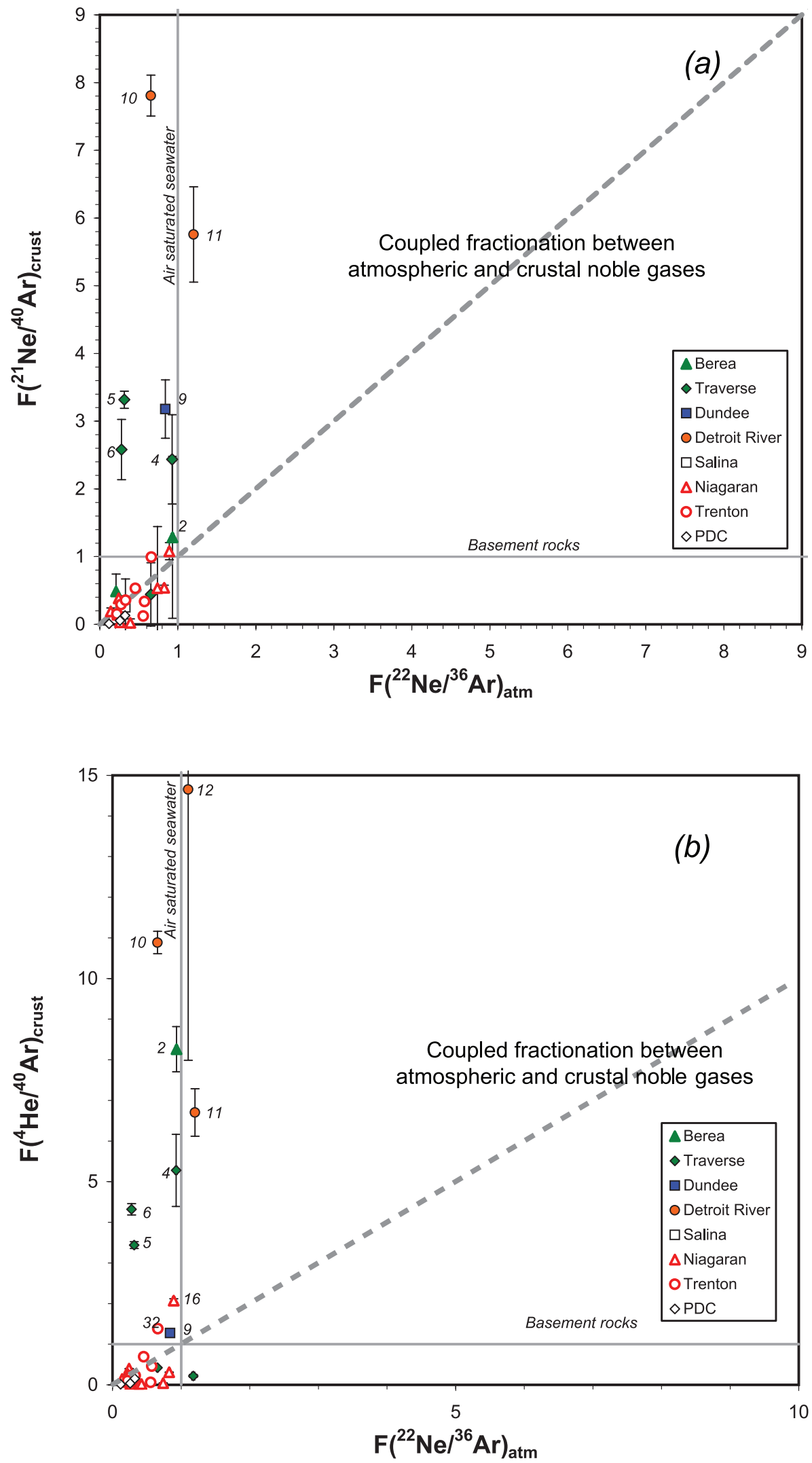

Figure 6 
scale of the study area and diversity of formations from which these brine samples are collected (Figures 1a and 1b). Despite this, it is apparent that a highly simplified Rayleigh Law model is largely capable of explaining the observed general pattern of noble gases elemental fractionation.

[33] As shown by Ma et al. [2009], atmospheric noble gas components in these brines show a highly depleted pattern with respect to ASW, a depletion pattern that is best explained by a model involving subsurface boiling and steam separation. While these brines lost a significant amount of atmospheric noble gases because of surface boiling, it is expected that the crustal noble gas component was equally lost at the time of this thermal event. Thus, current crustal noble gas concentrations in these brines are expected, for the most part, to be those resulting from accumulation of this component following the thermal event responsible also for the observed depletion of the atmospheric noble gas component. It is thus expected that fractionation of these two components would be largely independent. This is precisely what is shown in Figure 6. Indeed, if fractionation processes affecting these two components were related, a linear correlation between the atmospheric and crustal noble gas ratios (e.g., ${ }^{22} \mathrm{Ne} /{ }^{36} \mathrm{Ar}_{\text {atm }}$ and ${ }^{21} \mathrm{Ne} /{ }^{40} \mathrm{Ar}_{\text {crust }}$ ratios) would be observed [see also, e.g., Ballentine et al., 1991]. The Michigan brines show total absence of correlation between these ratios (Figures 6a and 6b), indicating that the fractionation processes responsible for the crustal and atmospheric noble gases are largely independent. This is also supported by the fact that the observed crustal noble gas fractionation could be explained by fractionation processes within a temperature range of $40-120^{\circ} \mathrm{C}$ (Figure 5), far lower than the expected $260^{\circ} \mathrm{C}$ boiling temperature during the depletion of atmospheric noble gases [Ma et al., 2009].

\subsection{Recent Reactivation of the Midcontinent Rift: An Internal Heat Source for Michigan Basin Brines}

[34] Indicators of past high temperatures in uppermost Precambrian and Paleozoic formations occur widely in the North American Midcontinent, for example in the Appalachian and Illinois Basin [e.g., Bethke and Marshak, 1990]. These have been commonly linked to the Appalachian and Ouachita orogenic activities and subsequent large-scale brine migrations expelled from these orogenic fold belts toward the cratonic interior [Oliver, 1986; Bethke and Marshak, 1990]. In the Michigan Basin, the occurrence of past high temperatures (up to $260^{\circ} \mathrm{C}$ ) has been similarly identified in a wealth of thermal studies based on a diversity of proxies (e.g., organic maturity data, stable isotopes, fluid inclusions, authigenic clay minerals, apatite fission track ages [Cercone and Lohmann, 1987; Cercone and Pollack, 1991; Crowley, 1991; Coniglio et al., 1994; Girard and Barnes, 1995; Luczaj et al., 2006]). However, until very recently it remained unclear whether such high past temperatures could be attributed to long-distance brine migration, and thus, an external heat source or instead, to a local, internal source. Indeed, with its massive Late Silurian and Early Devonian evaporite formations (Salina group), the Michigan Basin is also a major potential source of such hot brines [e.g., Hay et al., 1988; Liu et al., 2003]. Transport of heat and fluids from deeper parts of the basin along major faults and fracture zones connected to the Precambrian basement structures have been previously proposed to account for past high temperatures in the basin [Budai and Wilson, 1991; Coniglio et al., 1994; Girard and Barnes, 1995; Luczaj et al., 2006]. The occurrence of hot fluids flowing out of the Michigan Basin have also been suggested to account for the presence of hydrothermal dolomites in eastern Wisconsin [Luczaj, 2006] and northern Indiana [Yoo et al., 2000]. All these studies suggest the presence of an internal heat source within the Michigan Basin as being responsible for the past high temperatures without the involvement of large-scale brine migration from peripheral forming orogenic fold belts. In this study, the observed vertical elemental fractionation of crustal noble gases in Michigan brines strongly supports this hypothesis (Figures 4 and 5). As previously indicated by the mantle [Castro et al., 2009] and atmospheric [Ma et al., 2009] noble gas signatures

Figure 6. Comparison of the magnitude of fractionation $\mathrm{F}$ for the crustal and atmospheric noble gas components in Michigan brine samples. (a) $\mathrm{F}\left({ }^{21} \mathrm{Ne} /{ }^{40} \mathrm{Ar}\right)_{\text {crust }}$ versus $\mathrm{F}\left({ }^{22} \mathrm{Ne} /{ }^{36} \mathrm{Ar}\right)_{\text {atm }}$ and (b) $\mathrm{F}\left({ }^{4} \mathrm{He} /{ }^{40} \mathrm{Ar}\right)_{\text {crust }}$ versus $\mathrm{F}\left({ }^{22} \mathrm{Ne} /{ }^{36} \mathrm{Ar}\right)_{\text {atm }}$. $\mathrm{F}$ values of $\left({ }^{21} \mathrm{Ne} /{ }^{40} \mathrm{Ar}\right)_{\text {crust }}$ and $\left({ }^{4} \mathrm{He} /{ }^{40} \mathrm{Ar}\right)_{\text {crust }}$ are defined as being normalized to the predicted production ratio of the basement (Table 3). $\left({ }^{22} \mathrm{Ne} /{ }^{36} \mathrm{Ar}\right)_{\mathrm{atm}}$ ratios are normalized to the air saturated seawater value at $25^{\circ} \mathrm{C}[\mathrm{Ozima}$ and Podosek, 2002]. Dashed lines indicate the expected coupled fractionation between atmospheric and crustal noble gases if the elemental fractionation of the two components were dependent. Most of our brine samples do not follow such a trend, indicating that the fractionation of crustal noble gases is largely independent of that of the atmospheric noble gas components. 


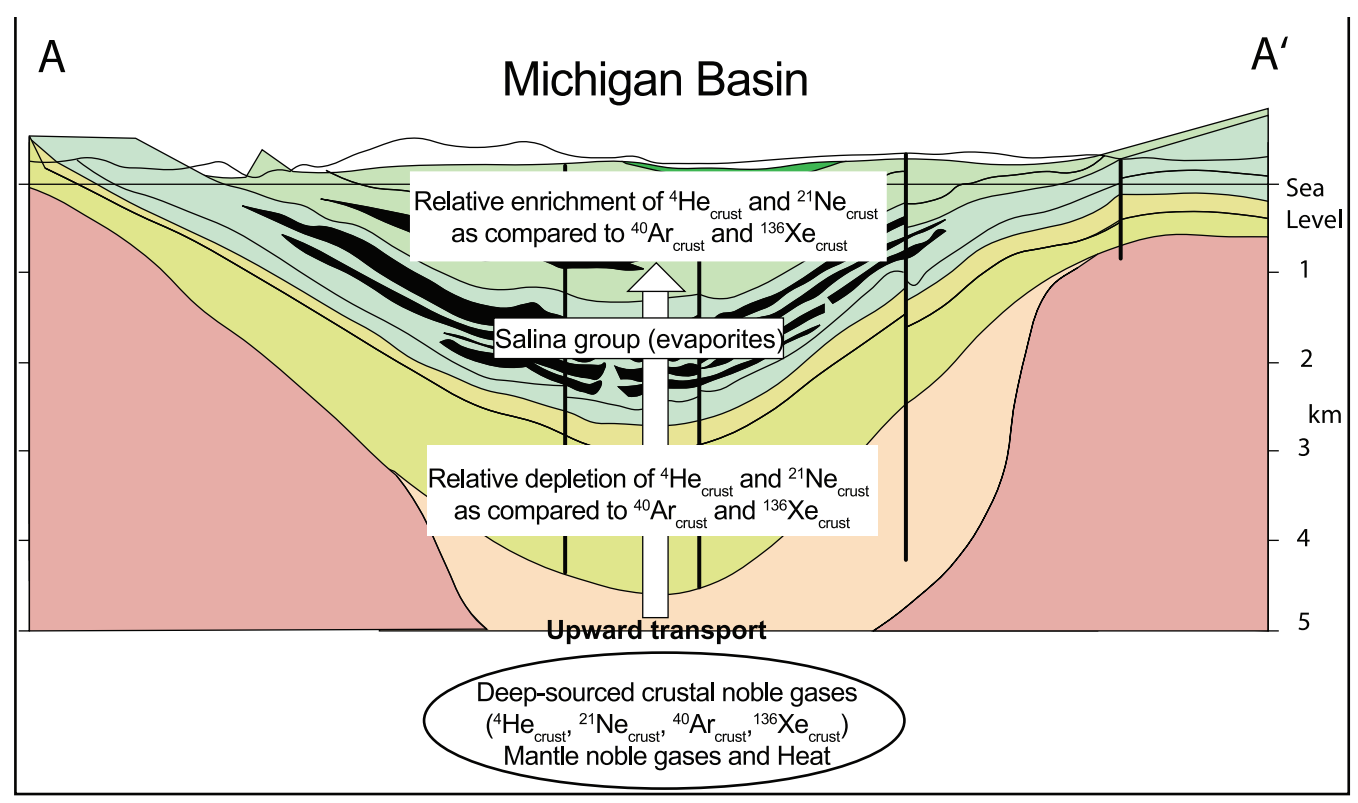

Figure 7. Schematic representation of a conceptual model for the release of the heat and mantle and crustal noble gases into the Michigan Basin due to the recent reactivation of the MCR underneath the Michigan Basin. Upward transport processes and associated elemental fractionation are responsible for the observed relative enrichment of ${ }^{4} \mathrm{He}_{\text {crust }}$ and ${ }^{21} \mathrm{Ne}_{\text {crust }}$ with respect to ${ }^{40} \mathrm{Ar}_{\text {crust }}$ and ${ }^{136} \mathrm{Xe}_{\text {crust }}$ in the shallow formations above the Salina group, as well as the complementary depletion of such components in deep formations. Legend of the cross section is the same as that of Figure 1c.

in Michigan Basin brines, release of deep crustal noble gases into the basin (Figure 7) which is likely still ongoing, is yet another independent tool pointing to the occurrence of a past thermal event in the basin. Recent reactivation of Precambrian basement structures is likely at the origin of such a thermal event and provides an internal heat source. Indeed, reactivation of the ancient MCR system during the Late Devonian-Mississippian (370$323 \mathrm{Ma}$ ) period was previously suggested on the basis of formation of authigenic illite, which yields the youngest ages $(323 \mathrm{Ma})$ and highest temperature estimates $\left(\sim 170^{\circ} \mathrm{C}\right)$ found so far in the vicinity of the MCR [Girard and Barnes, 1995]. Apatite fission track ages from drilled basement samples further indicate two additional, more recent periods of thermal activity, during the Triassic $(\sim 224 \mathrm{Ma})$ and Cretaceous ( 111-159 Ma) [Crowley, 1991]. Repeated movements along major faults prevailed throughout the early part of the Paleozoic and major uplift of the basin fault blocks occurred at the end of the Mississippian period [Fisher et al., 1988]. Reactivation of deep-seated faults and fractures in the basement of both southeastern and northeastern Michigan Basin has been suggested to account for the circulation of hot fluids (e.g., $220-260^{\circ} \mathrm{C}$ ) and formation of hydrothermal dolomite reservoirs [Sanford et al., 1985; Coniglio et al., 1994].
[35] Overall, our noble gas study of Michigan Basin brines [Castro et al., 2009; Ma et al., 2009; this study] shows that upward transport of heat and loss of the atmospheric noble gas component, as well as release of crustal and mantle noble gases are likely related to the recently reactivated MCR system, and supports the internal heat source hypothesis as being largely responsible for the existence of past high temperatures in the basin (Figure 7).

\section{Conclusions}

[36] We present noble gas concentrations and isotopic ratios from 38 deep brines $(\sim 0.5-3.6 \mathrm{~km})$ in the Michigan Basin. These brine samples clearly show the presence of an important crustal component of ${ }^{4} \mathrm{He}_{\text {crust }},{ }^{21} \mathrm{Ne}_{\text {crust }},{ }^{40} \mathrm{Ar}_{\text {crust }}$, and ${ }^{136} \mathrm{Xe}_{\text {crust }}$. Both ${ }^{40} \mathrm{Ar}_{\text {crust }}$ and ${ }^{136} \mathrm{Xe}_{\text {crust }}$ display the presence of a strong vertical gradient along the sedimentary strata of the Michigan Basin. It is shown that the in situ production for these two gases within the sedimentary strata is insufficient to account for the observed crustal components in the Michigan brines. These point to the presence of a deep, external source for crustal noble gases, likely the Precambrian crystalline basement beneath the Michigan Basin. Furthermore, the observed elemental ratios of crustal noble gases $\left({ }^{4} \mathrm{He} /{ }^{40} \mathrm{Ar}\right.$, ${ }^{21} \mathrm{Ne} /{ }^{40} \mathrm{Ar},{ }^{4} \mathrm{He} /{ }^{136} \mathrm{Xe}$, and ${ }^{21} \mathrm{Ne} /{ }^{136} \mathrm{Xe}$ ) vary over 
several orders of magnitude with respect to the expected production ratios of the crystalline basement rocks and display a systematic pattern within the basin. Specifically, samples above the Salina Group are enriched in ${ }^{4} \mathrm{He}_{\text {crust }}$ and ${ }^{21} \mathrm{Ne}_{\text {crust }}$ with respect to ${ }^{40} \mathrm{Ar}_{\text {crust }}$ and ${ }^{136} \mathrm{Xe}_{\text {crust }}$, as opposed to those below the massive Salina evaporite layer, which exhibit complementary patterns. We show that such a general trend is well explained by a Rayleigh-type elemental fractionation model involving upward transport of crustal noble gases and associated elemental fractionation processes, controlled by both diffusion- and solubility-related mechanisms. As previously indicated by the mantle and atmospheric noble gas signatures in Michigan Basin brines [Castro et al., 2009; Ma et al., 2009], release of deep crustal noble gases into the basin is yet another independent tool pointing to the occurrence of a past thermal event in the basin. We suggest that recent reactivation of the ancient midcontinent rift (MCR) system underneath the Michigan Basin is likely responsible for the upward transport of heat and loss of the atmospheric noble gas component, as well as release of crustal and mantle noble gases into the basin via deepseated faults and fracture zones. Such a conceptual model also supports the internal heat source hypothesis as being largely responsible for the existence of past high temperatures in the basin, without involvement of large-scale brine migration from peripheral forming orogenic fold belts.

\section{Acknowledgments}

[37] The authors thank V. Salters and an Associate Editor for the editorial handling of this manuscript as well as P. Burnard and J. Lippmann-Pipke for their thoughtful and constructive comments. We also thank B.R. Ellis for his assistance in the field and numerous private and public well owners for providing us with access to the wells. Financial support by the National Science Foundation CAREER award EAR-0545071 is greatly appreciated.

\section{References}

Ballentine, C. J., and P. G. Burnard (2002), Production, release and transport of noble gases in the continental crust, Rev. Mineral. Geochem., 47, 481-538, doi:10.2138/rmg. 2002.47.12.

Ballentine, C. J., R. K. O’Nions, E. R. Oxburgh, F. Horvath, and J. Deak (1991), Rare gas constraints on hydrocarbon accumulation, crustal degassing and groundwater flow in the Pannonian Basin, Earth Planet. Sci. Lett., 105, 229246, doi:10.1016/0012-821X(91)90133-3.

Ballentine, C. J., O’Nions R. K., and M. L. Coleman (1996), A Magnus opus: Helium, neon, and argon isotopes in a North Sea oilfield, Geochim. Cosmochim. Acta, 60, 831-849, doi:10.1016/0016-7037(95)00439-4.
Battani, A., P. Sarda, and A. Prinzhofer (2000), Basin scale natural gas source, migration and trapping traced by noble gases and major elements: The Pakistan Indus Basin, Earth Planet. Sci. Lett., 181, 229-249, doi:10.1016/S0012821X(00)00188-6.

Bethke, C. M., and S. Marshak (1990), Brine migrations across North America-The plate tectonics of groundwater, Annu. Rev. Earth Planet. Sci., 18, 287-315.

Bosch, A., and E. Mazor (1988), Natural gas association with water and oil as depicted by atmospheric noble gases: Case studies from the southeastern Mediterranean Coastal Plain, Earth Planet. Sci. Lett., 87, 338-346, doi:10.1016/0012821X(88)90021-0.

Brennwald, M. S., R. Kipfer, and D. M. Imboden (2005), Release of gas bubbles from lake sediment traced by noble gas isotopes in the sediment pore water, Earth Planet. Sci. Lett., 235, 31-44, doi:10.1016/j.eps1.2005.03.004.

Budai, J. M., and J. L. Wilson (1991), Diagenesis history of the Trenton and Black River formations in the Michigan Basin, in Early Sedimentary Evolution of the Michigan Basin, edited by P. A. Catacosinos and P. A. Daniels Jr., Spec. Pap. Geol. Soc. Am., vol. 256, pp. 73-88.

Burkland, M. K., T. D. Swindle, and S. L. Baldwin (1995), Isothermal heating experiments on Bjurbole: Implications for the release mechanisms of radiogenic ${ }^{129} \mathrm{Xe}$, Geochim. Cosmochim. Acta, 59, 2085-2094, doi:10.1016/00167037(95)00128-X.

Castro, M. C., and P. Goblet (2003), Calibration of regional groundwater flow models: Working toward a better understanding of site-specific systemsWater Resour. Res., 39(6), 1172, doi:10.1029/2002WR001653.

Castro, M. C., A. Jambon, G. de Marsily, and P. Schlosser (1998a), Noble gases as natural tracers of water circulation in the Paris Basin: 1. Measurements and discussion of their origin and mechanisms of vertical transport in the basin, Water Resour. Res., 34, 2443-2466, doi:10.1029/ 98WR01956.

Castro, M. C., P. Goblet, E. Ledoux, S. Violette, and G. de Marsily (1998b), Noble gases as natural tracers of water circulation in the Paris Basin: 2. Calibration of a groundwater flow model using noble gas isotope data, Water Resour. Res., 34, 2467-2483, doi:10.1029/98WR01957.

Castro, M. C., D. Patriarche, and P. Goblet (2005), 2-D numerical simulations of groundwater flow, heat transfer and ${ }^{4} \mathrm{He}$ transport-Implications for the He terrestrial budget and the mantle helium-heat imbalance, Earth Planet. Sci. Lett., 237, 893-910, doi:10.1016/j.epsl.2005.06.037.

Castro, M. C., L. Ma, and C. M. Hall (2009), A primordial, solar He-Ne signature in crustal fluids of a stable continental region, Earth Planet. Sci. Lett., 279, 174-184, doi:10.1016/ j.eps1.2008.12.042.

Catacosinos, P. A., P. A. Daniel Jr., and W. B. Harrison III (1991), Structure, stratigraphy, and petroleum geology of the Michigan Basin, in Interior Cratonic Basins, edited by M. W. Leighton et al., AAPG Mem., vol. 51, pp. 561-601.

Cercone, K. R. (1984), Thermal history of Michigan Basin, AAPG Bull., 68, 130-136.

Cercone, K. R., and K. C. Lohmann (1987), Late burial diagenesis of Niagaran (middle Silurian) pinnacle reefs in Michigan Basin, AAPG Bull., 71, 156-166.

Cercone, K. R., and H. N. Pollack (1991), Thermal maturity of the Michigan Basin, in Early Sedimentary Evolution of the Michigan Basin, edited by P. A. Catacosinos and P. A. Daniels Jr., Spec. Pap. Geol. Soc. Am., vol. 256, pp. 1-11. Coniglio, M., R. Sherlock, A. E. Williams-Jones, K. Middleton, and S. K. Frape (1994), Burial and hydrothermal diagenesis of 
Ordovician carbonates from the Michigan Basin, Ontario, Canada, Spec. Publ. Int. Assoc. Sedimentol., 21, 231-254.

Copeland, P., E. B. Watson, S. C. Urizar, D. Patterson, and T. J. Lapen (2007), Alpha thermochronology of carbonates, Geochim. Cosmochim. Acta, 71, 4488-4511, doi:10.1016/ j.gca.2007.07.004.

Crovetto, R., R. Fernandez-Prini, and M. L. Japas (1982), Solubilities of inert gases and methane in $\mathrm{H}_{2} \mathrm{O}$ and in $\mathrm{D}_{2} \mathrm{O}$ in the temperature range of 300 to 600K, J. Chem. Phys., 76, 1077-1086, doi:10.1063/1.443074.

Crowley, K. D. (1991), Thermal history of Michigan Basin and southern Canadian Shield from apatite fission track analysis, J. Geophys. Res., 96, 697-711, doi:10.1029/90JB02174.

Davisson, M. L., and R. E. Criss (1996), Na-Ca-Cl relations in basinal fluids, Geochim. Cosmochim. Acta, 60, 2743-2752, doi:10.1016/0016-7037(96)00143-3.

Dodson, M. H. (1973), Closure temperature in cooling geochronological and petrological systemsContrib. Mineral. Petrol., 40, 259-274, doi:10.1007/BF00373790.

Dolton, G. L. (1995), Michigan Basin Province (063), in 1995 National Assessment of United States Oil and Gas Resources: Results, Methodology, and Supporting Data [CDROM], Digital Data Ser. DDS-30, edited by D. L. Gautier et al., U.S. Geol. Surv., Denver, Colo.

Dorr, J. A., Jr., and D. F. Eschman (1970), Geology of Michigan, 1st ed., Univ. of Mich. Press, Ann Arbor.

Eikenberg, J., P. Signer, and R. Wieler (1993), U-Xe, U-Kr, and $\mathrm{U}-\mathrm{Pb}$ systematics for dating uranium minerals and investigations of the production of nucleogenic neon and argon, Geochim. Cosmochim. Acta, 57, 1053-1069, doi:10.1016/0016-7037(93)90040-4.

Fisher, J. H., M. W. Barratt, J. B. Droste, and R. H. Shaver (1988), Michigan Basin, in Sedimentary Cover-North America Craton, The Geology of North America, vol. D-2, edited by L. L. Sloss, pp. 361-382, Geol. Soc. of Am., Boulder, Colo.

Gautheron, C. E., L. Tassan-Got, and K. A. Farley (2006), (UTh)/Ne chronometry, Earth Planet. Sci. Lett., 243, 520-535, doi:10.1016/j.epsl.2006.01.025.

Girard, J.-P., and D. A. Barnes (1995), Illitization and paleothermal regimes in the middle Ordovician St. Peter sandstone, central Michigan Basin: K-Ar, oxygen isotope, and fluid inclusion data, AAPG Bull., 79, 49-69.

Graham, D. W. (2002), Noble gas isotope geochemistry of mid-ocean ridge and ocean island basalts: Characterization of mantle source reservoirs, Rev. Mineral. Geochem., 47, 247-318, doi:10.2138/rmg.2002.47.8.

Hay, R. L., M. Lee, D. R. Kolata, J. C. Matthews, and J. P. Morton (1988), Episodic potassic diagenesis of Ordovician tuffs in the Mississippi Valley area, Geology, 16, 743-747, doi:10.1130/0091-7613(1988)016<0743:EPDOOT $>2.3$. $\mathrm{CO} ; 2$.

Hinze, W. J., R. L. Kellogg, and N. W. O'Hara (1975), Geophysical studies of basement geology of southern peninsula of Michigan, AAPG Bull., 59, 1562-1584.

Hiyagon, H., and B. M. Kennedy (1992), Noble gases in $\mathrm{CH}_{4}$ rich gas fields, Alberta, Canada, Geochim. Cosmochim. Acta, 56, 1569-1589, doi:10.1016/0016-7037(92)90226-9.

Honda, M., A. P. Nutman, V. C. Bennett, and I. Yatsevich (2004), Radiogenic, nucleogenic and fissiongenic noble gas compositions in early Archaean magmatic zircons from Greenland, Geochem. J., 38, 265-269.

Jähne, B., G. Heinz, and W. Dietrich (1987), Measurement of the diffusion coefficients of sparingly soluble gases in water, J. Geophys. Res., 92, 10,767-10,776, doi:10.1029/ JC092iC10p10767.
Kulongoski, J. T., D. R. Hilton, and J. A. Izbicki (2005), Source and movement of helium in the eastern Morongo groundwater Basin: The influence of regional tectonic on crustal and mantle helium fluxes, Geochim. Cosmochim. Acta, 69, 3857-3872, doi:10.1016/j.gca.2005.03.001.

Lippmann, J., M. Stute, T. Torgersen, D. Moser, J. A. Hall, L. Lin, M. Borcsik, R. E. S. Bellamy, and T. C. Onstott (2003), Dating ultra-deep mine waters with noble gases and ${ }^{36} \mathrm{Cl}$, Witwatersrand Basin, South Africa, Geochim. Cosmochim. Acta, 67(23), 4597-4619, doi:10.1016/ S0016-7037(03)00414-9.

Lippolt, H. J., and E. Weigel (1988), ${ }^{4} \mathrm{He}$ diffusion in ${ }^{40} \mathrm{Ar}-$ retentive minerals, Geochim. Cosmochim. Acta, 52, 14491458, doi:10.1016/0016-7037(88)90215-3.

Liu, J., R. L. Hay, A. Deino, and T. K. Kyser (2003), Age and origin of authigenic K-feldspar in uppermost Precambrian rocks in the North American Midcontinent, Geol. Soc. Am. Bull., 115, 422-433, doi:10.1130/0016-7606(2003)115< 0422:AAOOAK > 2.0.CO;2.

Long, D. T., T. P. Wilson, M. J. Takacs, and D. H. Rezabek (1988), Stable-isotope geochemistry of saline near-surface ground water: East-central Michigan Basin, Geol. Soc. Am. Bull., 100, 1568-1577, doi:10.1130/0016-7606(1988)100< 1568: SIGOSN $>2.3 . \mathrm{CO} ; 2$

Luczaj, J. A. (2006), Evidence against the Dorag (mixingzone) model for dolomitization along the Wisconsin archA case for hydrothermal diagenesis, AAPG Bull., 90, 17191738, doi:10.1306/01130605077.

Luczaj, J. A., W. B. Harrison III, and N. S. Williams (2006), Fractured hydrothermal dolomite reservoirs in the Devonian Dundee formation of the central Michigan Basin, $A A P G$ Bull., 90, 1787-1801, doi:10.1306/06270605082.

Ma, L., M. C. Castro, and C. M. Hall (2004), A late Pleistocene-Holocene noble gas paleotemperature record in southern Michigan, Geophys. Res. Lett., 31, L23204, doi:10.1029/ 2004GL021766.

Ma, L., M. C. Castro, C. M. Hall, and L. M. Walter (2005), Cross-formational flow and salinity sources inferred from a combined study of helium concentrations, isotopic ratios, and major elements in the Marshall aquifer, southern Michigan, Geochem. Geophys. Geosyst., 6, Q10004, doi:10.1029/ 2005GC001010.

Ma, L., M. C. Castro, and C. M. Hall (2009), Atmospheric noble gas signatures in deep Michigan Basin brines as indicators of a past thermal event, Earth Planet. Sci. Lett., 277, 137-147, doi:10.1016/j.eps1.2008.10.015.

Martini, A. M. (1997), Hydrogeochemistry of saline fluids and associated water and gas, Ph.D. dissertation, Univ. of Michigan, Ann Arbor.

McIntosh, J. C., L. M. Walter, and A. M. Martini (2004), Extensive microbial modification of formation water geochemistry: Case study from a mid-continent sedimentary basin, United States, Geol. Soc. Am. Bull., 116, 743-759, doi:10.1130/B25371.1.

Menuge, J. F., T. S. Brewer, and C. M. Seeger (2002), Petrogenesis of metaluminous A-type rhyolites from the St Francois Mountains, Missouri and the Mesoproterozoic evolution of the southern Laurentian margin, Precambrian Res., 113 , 269-291, doi:10.1016/S0301-9268(01)00211-X.

Ohsumi, T., and Y. Horibe (1984), Diffusivity of He and Ar in deep-sea sediments, Earth Planet. Sci. Lett., 70, 61-68, doi:10.1016/0012-821X(84)90209-7.

Oliver, J. E. (1986), Fluids expelled tectonically from orogenic belts: Their role in hydrocarbon migration and other geologic phenomena, Geology, 14, 99-102, doi:10.1130/00917613(1986) $14<99$ :FETFOB >2.0.CO;2. 
O'Nions, R. K., and C. J. Ballentine (1993), Rare gas studies of basin scale fluid movement, Philos. Trans. $R$. Soc. London, Ser. A, 344, 141-156, doi:10.1098/rsta. 1993.0082.

Oxburgh, E. R., O’Nions R. K., and R. I. Hill (1986), Helium isotopes in sedimentary basins, Nature, 324, 632-635, doi:10.1038/324632a0.

Ozima, M., and F. A. Podosek (2002), Noble Gas Geochemistry, 2nd ed., 286 pp., Cambridge Univ. Press, New York.

Parker, R. L. (1967), Composition of Earth's crust, data of geochemistry, U. S. Geol. Surv. Prof. Pap., 440-D, 1-19.

Patriarche, D., M. C. Castro, and P. Goblet (2004), Large-scale hydraulic conductivities inferred from three-dimensional groundwater flow and ${ }^{4} \mathrm{He}$ transport modeling in the Carrizo aquifer, Texas, J. Geophys. Res., 109, B11202, doi:10.1029/ 2004JB003173.

Pinti, D. L., and B. Marty (1995), Noble gases in crude oils from the Paris Basin, France: Implications for the origin of fluids and constraints on oil-water-gas interactions, Geochim. Cosmochim. Acta, 59, 3389-3404, doi:10.1016/ 0016-7037(95)00213-J.

Rudnick, R. L., and D. M. Fountain (1995), Nature and composition of the continental crust: A lower crustal perspective, Rev. Geophys., 33, 267-309, doi:10.1029/95RG01302.

Saar, M. O., M. C. Castro, C. M. Hall, M. Manga, and T. P. Rose (2005), Quantifying magmatic, crustal, and atmospheric helium contributions to volcanic aquifers using all stable noble gases: Implications for magmatism and groundwater flow, Geochem. Geophys. Geosyst., 6, Q03008, doi:10.1029/2004GC000828.

Sanford, B. V., F. J. Thompson, and G. H. McFall (1985), Plate tectonics-a possible controlling mechanism in the development of hydrocarbon traps in southwestern Ontario, Bull. Can. Pet. Geol., 33, 52-71.

Shaw, D. M. (1967), U, Th and K in the Canadian Precambrian shield and possible mantle compositions, Geochim. Cosmochim. Acta, 31, 1111-1113, doi:10.1016/0016-7037(67) 90087-7.

Smith, S. P. (1985), Noble gas solubility in water at high temperatures, Eos Trans. AGU, 66, 397.

Smith, S. P., and B. M. Kennedy (1983), The solubility of noble gases in water and in $\mathrm{NaCl}$ brine, Geochim. Cosmochim. Acta, 47, 503-515, doi:10.1016/0016-7037(83)90273-9.

Torgersen, T., and W. B. Clarke (1985), Helium accumulation in groundwater; I. an evaluation of sources and the continental flux of crustal ${ }^{4} \mathrm{He}$ in the Great Artesian Basin, Australia, Geochim. Cosmochim. Acta, 49, 2445-2452, doi:10.1016/ 0016-7037(85)90244-3.

Torgersen, T., B. M. Kennedy, H. Hiyagon, K. Y. Chiou, J. H. Reynolds, and W. B. Clarke (1989), Argon accumulation and the crustal degassing flux of ${ }^{40} \mathrm{Ar}$ in the Great Artesian Ba- sin, Australia, Earth Planet. Sci. Lett., 92, 43-56, doi:10.1016/0012-821X(89)90019-8.

Van Schmus, W. R. (1992), Tectonic setting of the Midcontinent Rift system, Tectonophysics, 213, 1-15, doi:10.1016/ 0040-1951(92)90247-4.

Vugrinovich, R. (1986), Patterns of regional subsurface fluid movement in the Michigan Basin, U.S. Geol. Surv. Open File., 86-6.

Vugrinovich, R. (1988), Shale compaction in the Michigan Basin: Estimates of former depth of burial and implications for paleogeothermal gradients, Bull. Can. Pet. Geol., 36, 1-8.

Vugrinovich, R. (1989), Subsurface temperatures and surface heat flow in the Michigan Basin and their relationships to regional subsurface fluid movement, Mar. Pet. Geol., 6, 60 70, doi:10.1016/0264-8172(89)90076-7.

Weiss, R. F. (1968), Piggyback sampler for dissolved gas studies on sealed water samples, Deep Sea Res. Oceanogr. Abstr., 15, 695-699, doi:10.1016/0011-7471(68)90082-X.

Wetherill, G. W. (1953), Spontaneous fission yields from uranium and thorium, Phys. Rev., 92, 907-912, doi:10.1103/ PhysRev.92.907.

Wetherill, G. W. (1954), Variations in the isotopic abundances of neon and argon extracted from radioactive minerals, Phys. Rev., 96, 679-683, doi:10.1103/PhysRev.96.679.

Wilson, T. P., and D. T. Long (1993a), Geochemistry and isotope chemistry of Michigan Basin brines: Devonian formations, Appl. Geochem., 8, 81-100, doi:10.1016/08832927(93)90058-O.

Wilson, T. P., and D. T. Long (1993b), Geochemistry and isotope chemistry of $\mathrm{Ca}-\mathrm{Na}-\mathrm{Cl}$ brines in Silurian strata, Michigan Basin, Appl. Geochem., 8, 507-524, doi:10.1016/ 0883-2927(93)90079-V.

Wise, D. L., and G. Houghton (1966), The diffusion coefficients of ten slightly soluble gases in water at $10-60^{\circ} \mathrm{C}$, Chem. Eng. Sci., 21, 999-1010, doi:10.1016/00092509(66)85096-0.

Wise, D. L., and G. Houghton (1968), Diffusion coefficients of neon, krypton, xenon, carbon monoxide and nitric oxide in water at $10-60^{\circ} \mathrm{C}$, Chem. Eng. Sci., 23, 1211-1216, doi:10.1016/0009-2509(68)89029-3.

Yoo, C. M., J. M. Gregg, and K. L. Shelton (2000), Dolomitization and dolomite neomorphism: Trenton and Black River limestones (middle Ordovician) northern Indiana, U.S.A., J. Sediment. Res., 70, 265-274, doi:10.1306/2DC409100E47-11D7-8643000102C1865D.

Zaikowski, A., B. J. Kosanke, and N. Hubbard (1987), Noble gas composition of deep brines from the Palo Duro Basin, Texas, Geochim. Cosmochim. Acta, 51, 73-84, doi:10.1016/ 0016-7037(87)90008-1.

Zartman, R. E., G. J. Wasserburg, and J. H. Reynolds (1961), Helium, argon, and carbon in some natural gases, J. Geophys. Res., 66, 277-306, doi:10.1029/JZ066i001p00277. 